\title{
LEVEL II SCOUR ANALYSIS FOR BRIDGE 13 (POMFTH00020013) on TOWN HIGHWAY 2, crossing BARNARD BROOK, POMFRET, VERMONT
}

U.S. Geological Survey Open-File Report 96-583

Prepared in cooperation with

VERMONT AGENCY OF TRANSPORTATION and

FEDERAL HIGHWAY ADMINISTRATION 


\section{LEVEL II SCOUR ANALYSIS FOR BRIDGE 13 (POMFTH00020013) on TOWN HIGHWAY 2, crossing BARNARD BROOK, POMFRET, VERMONT \\ By MICHAEL A. IVANOFF}

U.S. Geological Survey Open-File Report 96-583

Prepared in cooperation with

VERMONT AGENCY OF TRANSPORTATION

and

FEDERAL HIGHWAY ADMINISTRATION 


\title{
U.S. DEPARTMENT OF THE INTERIOR BRUCE BABBITT, Secretary
}

\author{
U.S. GEOLOGICAL SURVEY \\ Gordon P. Eaton, Director
}

For additional information write to:

District Chief

U.S. Geological Survey 361 Commerce Way

Pembroke, NH 03275-3718
Copies of this report may be purchased from:

U.S. Geological Survey

Branch of Information Services

Open-File Reports Unit

Box 25286

Denver, CO 80225-0286 


\section{CONTENTS}

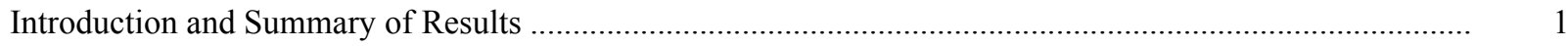

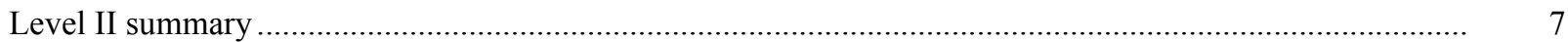

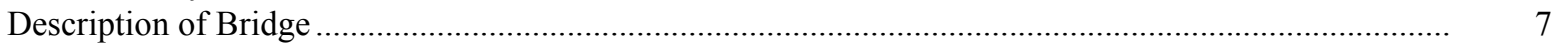

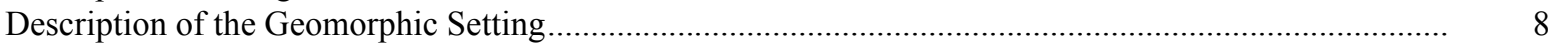

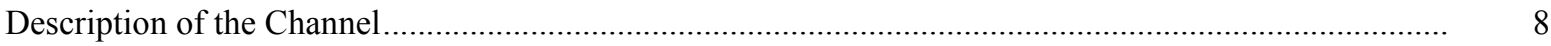

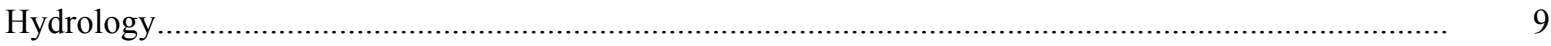

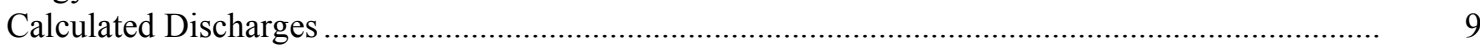

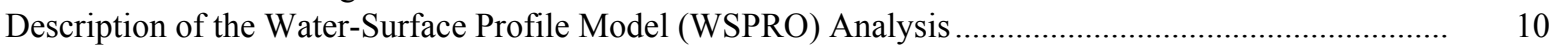

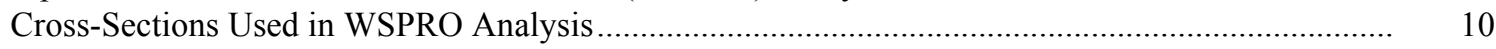

Data and Assumptions Used in WSPRO Model ...................................................................... 11

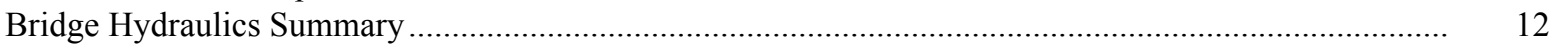

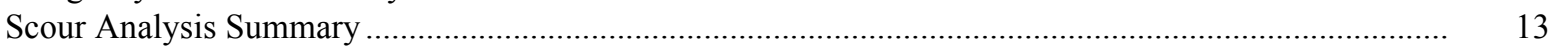

Special Conditions or Assumptions Made in Scour Analysis ...................................................... 13

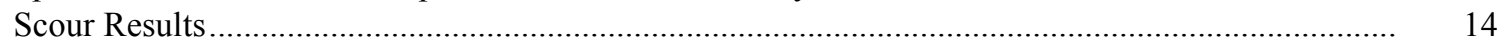

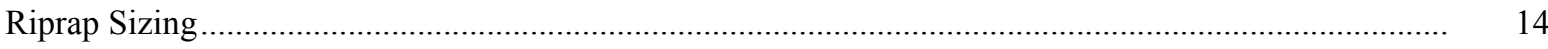

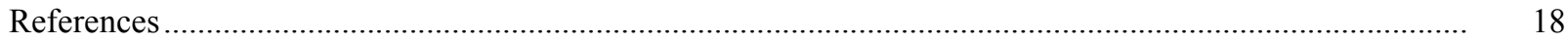

Appendixes:

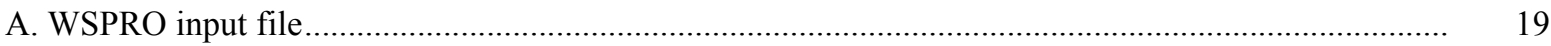

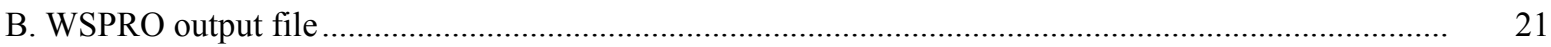

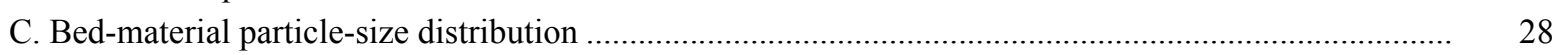

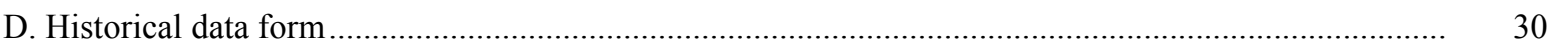

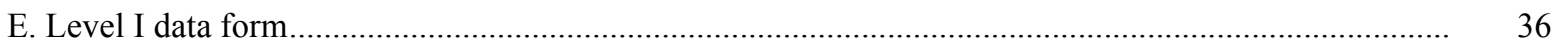

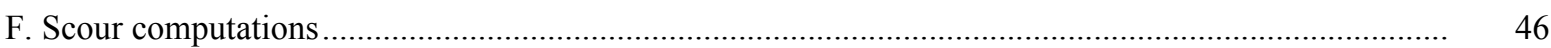

\section{FIGURES}

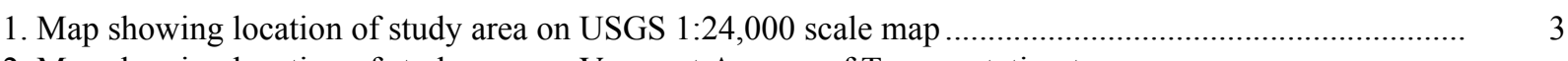

2. Map showing location of study area on Vermont Agency of Transportation town
highway map

3. Structure POMFTH00020013 viewed from upstream (September 15, 1994) ........................................ 5

4. Downstream channel viewed from structure POMFTH00020013 (September 15, 1994). ...................... 5

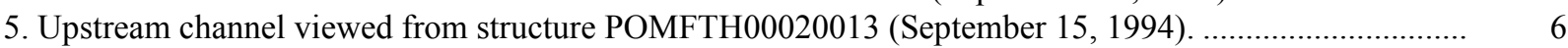

6. Structure POMFTH00020013 viewed from downstream (September 15, 1994) .................................. 6

7. Water-surface profiles for the 100- and 500-year discharges at structure

POMFTH00020013 on Town Highway 2, crossing Barnard Brook,

Pomfret, Vermont.

8. Scour elevations for the 100- and 500-year discharges at structure

POMFTH00020013 on Town Highway 2, crossing Barnard Brook,

Pomfret, Vermont.

\section{TABLES}

1. Remaining footing/pile depth at abutments for the 100-year discharge at structure

POMFTH00020013 on Town Highway 2, crossing Barnard Brook,

Pomfret, Vermont.

2. Remaining footing/pile depth at abutments for the 500-year discharge at structure

POMFTH00020013 on Town Highway 2, crossing Barnard Brook,

Pomfret, Vermont. 


\begin{tabular}{|c|c|c|}
\hline Multiply & By & To obtain \\
\hline \multicolumn{3}{|c|}{ Length } \\
\hline inch (in.) & 25.4 & millimeter (mm) \\
\hline foot $(\mathrm{ft})$ & 0.3048 & $\operatorname{meter}(\mathrm{m})$ \\
\hline mile (mi) & 1.609 & kilometer (km) \\
\hline \multicolumn{3}{|c|}{ Slope } \\
\hline foot per mile ( $\mathrm{ft} / \mathrm{mi})$ & 0.1894 & meter per kilometer $(\mathrm{m} / \mathrm{km})$ \\
\hline \multicolumn{3}{|c|}{ Area } \\
\hline square mile $\left(\mathrm{mi}^{2}\right)$ & 2.590 & square kilometer $\left(\mathrm{km}^{2}\right)$ \\
\hline \multicolumn{3}{|c|}{ Volume } \\
\hline cubic foot $\left(\mathrm{ft}^{3}\right)$ & $\begin{array}{l}0.02832 \\
\text { Velocity and Flow }\end{array}$ & cubic meter $\left(\mathrm{m}^{3}\right)$ \\
\hline foot per second $(\mathrm{ft} / \mathrm{s})$ & 0.3048 & meter per second $(\mathrm{m} / \mathrm{s})$ \\
\hline cubic foot per second $\left(\mathrm{ft}^{3} / \mathrm{s}\right)$ & 0.02832 & cubic meter per second $\left(\mathrm{m}^{3} / \mathrm{s}\right)$ \\
\hline $\begin{array}{l}\text { cubic foot per second per } \\
\text { square mile } \\
{\left[\left(\mathrm{ft}^{3} / \mathrm{s}\right) / \mathrm{mi}^{2}\right]}\end{array}$ & 0.01093 & $\begin{array}{l}\text { cubic meter per } \\
\text { second per square } \\
\text { kilometer }\left[\left(\mathrm{m}^{3} / \mathrm{s}\right) / \mathrm{km}^{2}\right]\end{array}$ \\
\hline
\end{tabular}

OTHER ABBREVIATIONS

$\begin{array}{lrlr}\mathrm{BF} & \text { bank full } & \text { LWW } & \text { left wingwall } \\ \mathrm{cfs} & \text { cubic feet per second } & \text { MC } & \text { main channel } \\ \mathrm{D}_{50} & \text { median diameter of bed material } & \text { RAB } & \text { right abutment } \\ \mathrm{DS} & \text { downstream } & \text { RABUT } & \text { face of right abutment } \\ \mathrm{elev} & \text { elevation } & \text { RB } & \text { right bank } \\ \mathrm{f} / \mathrm{p} & \text { flood plain } & \text { ROB } & \text { right overbank } \\ \mathrm{ft} & \text { square feet } & \text { RWW } & \text { right wingwall } \\ \mathrm{ft} / \mathrm{ft} & \text { feet per foot } & \text { TH } & \text { town highway } \\ \mathrm{JCT} & \text { junction } & \text { UB } & \text { under bridge } \\ \mathrm{LAB} & \text { left abutment } & \text { US } & \text { upstream } \\ \mathrm{LABUT} & \text { face of left abutment } & \text { USGS } & \text { United States Geological Survey } \\ \text { LB } & \text { left bank } & \text { VTAOT Vermont Agency of Transportation } \\ \text { LOB } & \text { left overbank } & \text { WSPRO } & \text { water-surface profile model }\end{array}$

In this report, the words "right" and "left" refer to directions that would be reported by an observer facing downstream. Sea level: In this report, "sea level" refers to the National Geodetic Vertical Datum of 1929-- a geodetic datum derived from a general adjustment of the first-order level nets of the United States and Canada, formerly called Sea Level Datum of 1929.

In the appendices, the above abbreviations may be combined. For example, USLB would represent upstream left bank. 


\title{
LEVEL II SCOUR ANALYSIS FOR BRIDGE 13 (POMFTH00020013) ON TOWN HIGHWAY 2, CROSSING BARNARD BROOK, POMFRET, VERMONT
}

\author{
By Michael A. Ivanoff
}

\section{INTRODUCTION AND SUMMARY OF RESULTS}

This report provides the results of a detailed Level II analysis of scour potential at structure POMFTH00020013 on town highway 2 crossing Barnard Brook, Pomfret, Vermont (figures 1-8). A Level II study is a basic engineering analysis of the site, including a quantitative analysis of stream stability and scour (U.S. Department of Transportation, 1993). Results of a Level I scour investigation also are included in Appendix E of this report. A Level I study provides a qualitative geomorphic characterization of the study site. Information on the bridge, gleaned from Vermont Agency of Transportation (VTAOT) files, was compiled prior to conducting Level I and Level II analyses and can be found in Appendix D.

The site is in the New England Upland section of the New England physiographic province of east-central Vermont in the town of Pomfret. The 7.98- $\mathrm{mi}^{2}$ drainage area is in a predominantly rural and forested basin. In the vicinity of the study site, the surface cover is primarily field grasses with some brush on the immediate banks.

In the study area, Barnard Brook has an incised, sinuous channel with a slope of approximately $0.006 \mathrm{ft} / \mathrm{ft}$, an average channel top width of $32 \mathrm{ft}$ and an average channel depth of $4 \mathrm{ft}$. The predominant channel bed materials are gravel and cobbles with a median grain size $\left(\mathrm{D}_{50}\right)$ of $51.0 \mathrm{~mm}(0.167 \mathrm{ft})$. The geomorphic assessment at the time of the Level I and Level II site visit on September 15, 1994, indicated that the reach was stable.

The town highway 2 crossing of Barnard Brook is a 23-ft-long, two-lane bridge consisting of one 20-foot concrete span (Vermont Agency of Transportation, written communication, August 22, 1994). The bridge is supported by vertical, concrete abutments with wingwalls. The channel is skewed approximately 30 degrees to the opening while the opening-skew-toroadway is 0 degrees.

Scour, $2.5 \mathrm{ft}$ deeper than the mean thalweg depth, was observed along the left abutment during the Level I assessment. The only scour protection measure at the site was type-2 stone fill (less than 36 inches diameter) along the base and upstream of the upstream left wingwall. Additional details describing conditions at the site are included in the Level II Summary and Appendices D and E. 
Scour depths and rock rip-rap sizes were computed using the general guidelines described in Hydraulic Engineering Circular 18 (Richardson and others, 1995). Total scour at a highway crossing is comprised of three components: 1) long-term streambed degradation; 2) contraction scour (due to accelerated flow caused by a reduction in flow area at a bridge) and; 3) local scour (caused by accelerated flow around piers and abutments). Total scour is the sum of the three components. Equations are available to compute depths for contraction and local scour and a summary of the results of these computations follows.

Contraction scour for all modelled flows ranged from 0.0 to $1.5 \mathrm{ft}$. The worst-case contraction scour occurred at the 100-year discharge. Abutment scour ranged from 7.2 to $12.6 \mathrm{ft}$. The worst-case abutment scour occurred at the 500-year discharge. Additional information on scour depths and depths to armoring are included in the section titled "Scour Results". Scoured-streambed elevations, based on the calculated scour depths, are presented in tables 1 and 2. A cross-section of the scour computed at the bridge is presented in figure 8. Scour depths were calculated assuming an infinite depth of erosive material and a homogeneous particle-size distribution.

It is generally accepted that the Froehlich equation (abutment scour) gives "excessively conservative estimates of scour depths" (Richardson and others, 1995, p. 47). Usually, computed scour depths are evaluated in combination with other information including (but not limited to) historical performance during flood events, the geomorphic stability assessment, existing scour protection measures, and the results of the hydraulic analyses. Therefore, scour depths adopted by VTAOT may differ from the computed values documented herein. 


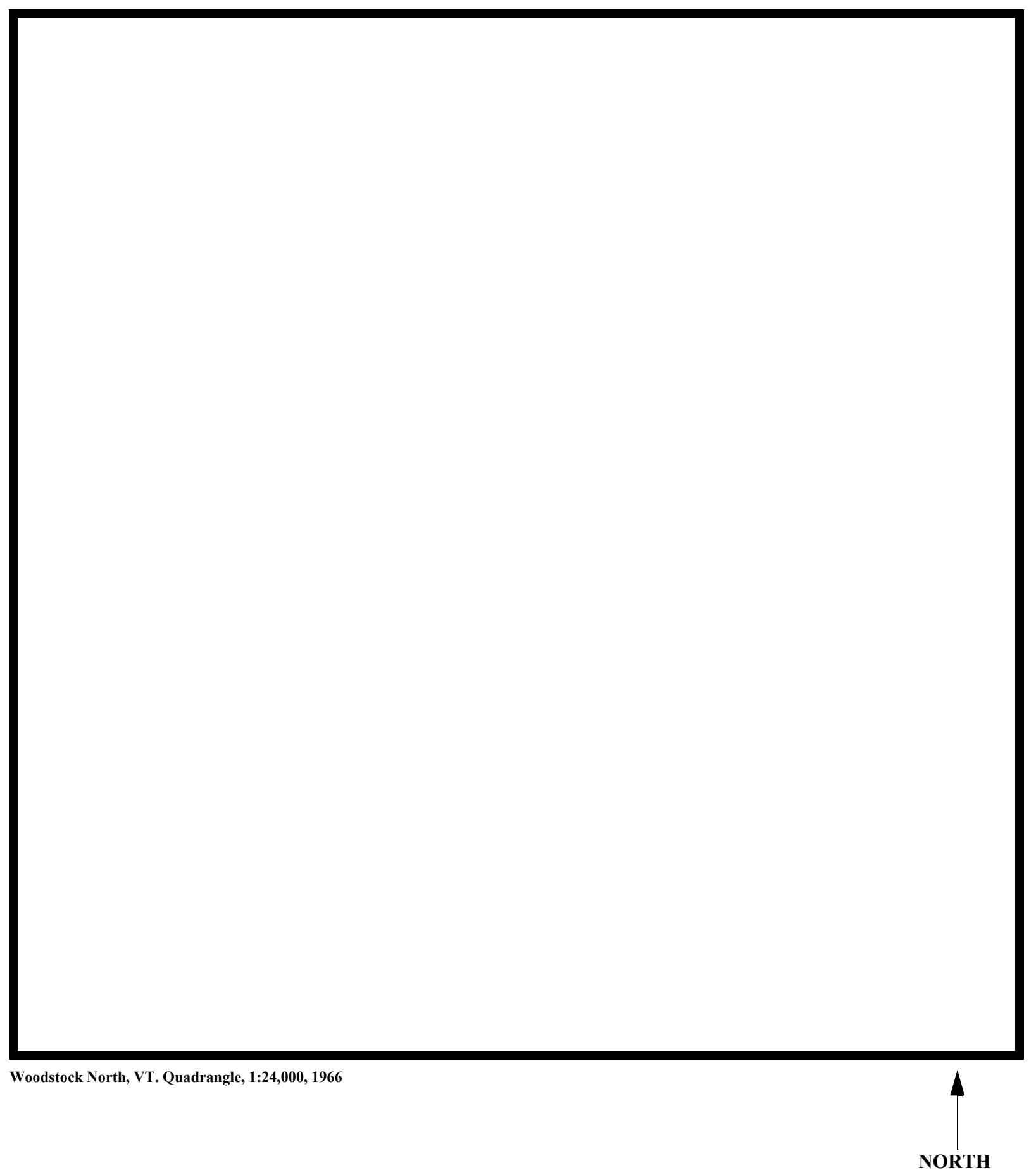

Figure 1. Location of study area on USGS 1:24,000 scale map. 
Figure 2. Location of study area on Vermont Agency of Transportation town highway map. 

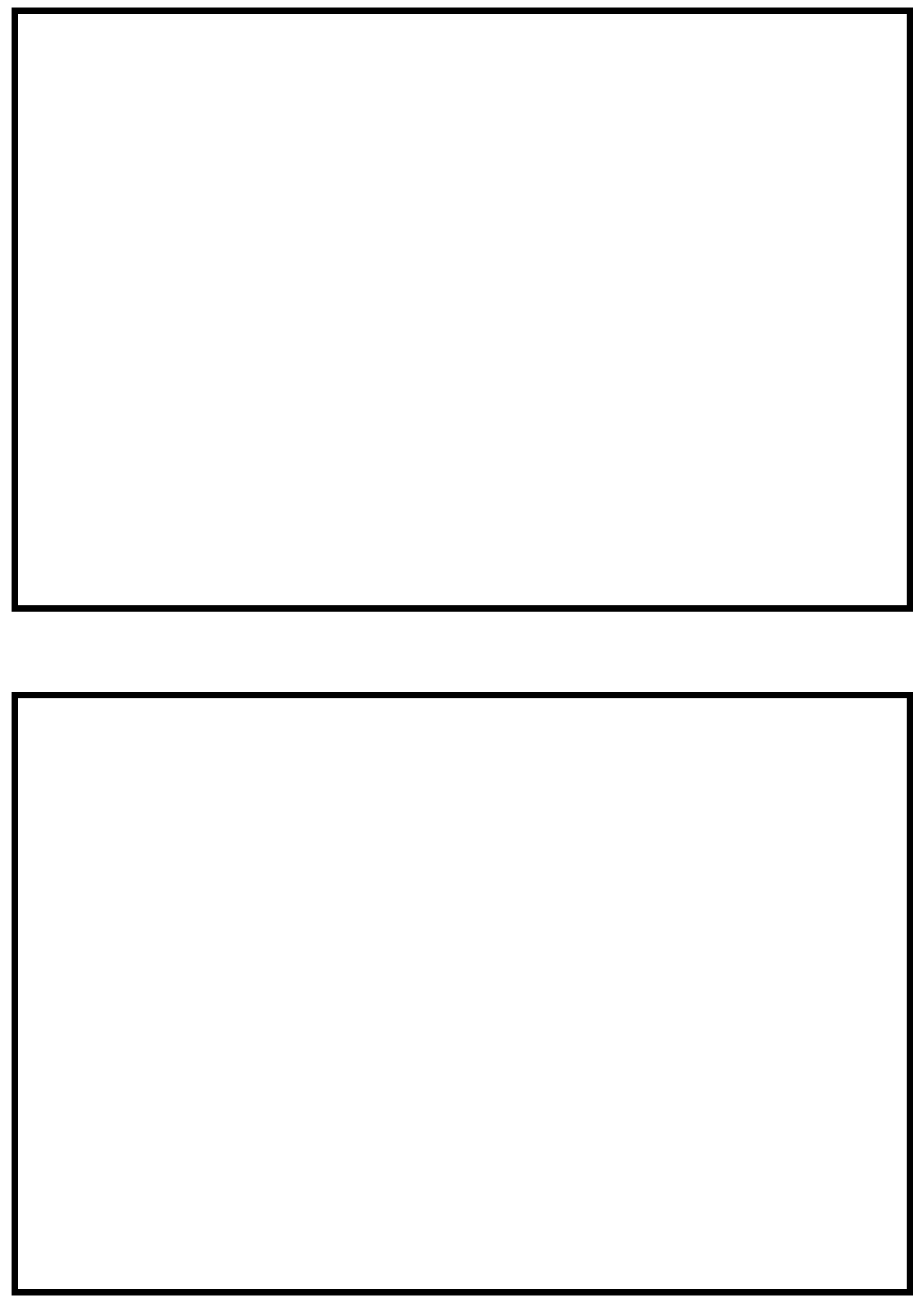

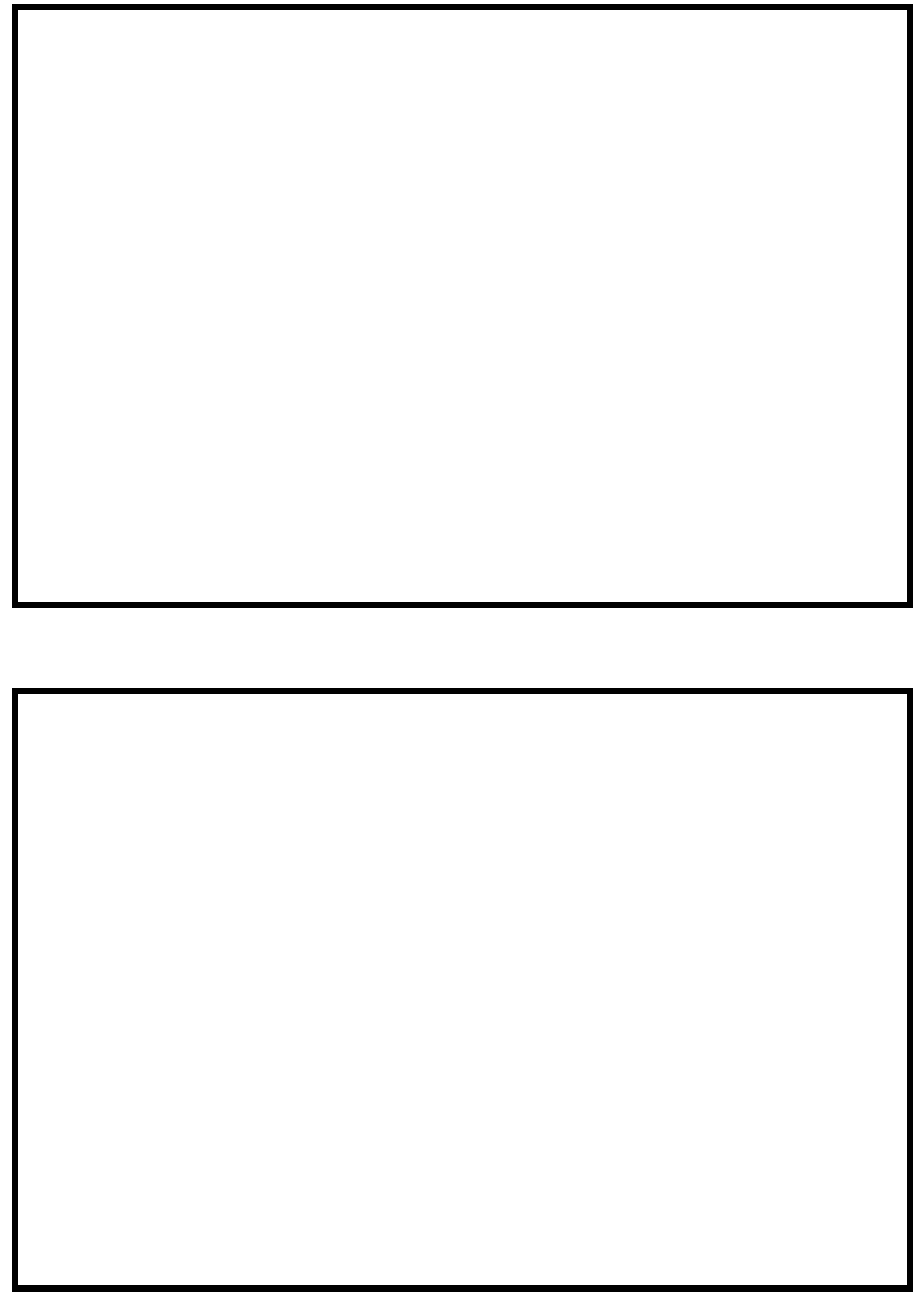


\section{LEVEL II SUMMARY}

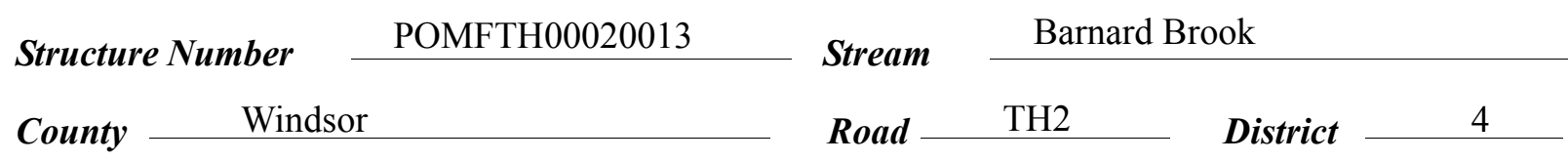

\section{Description of Bridge}

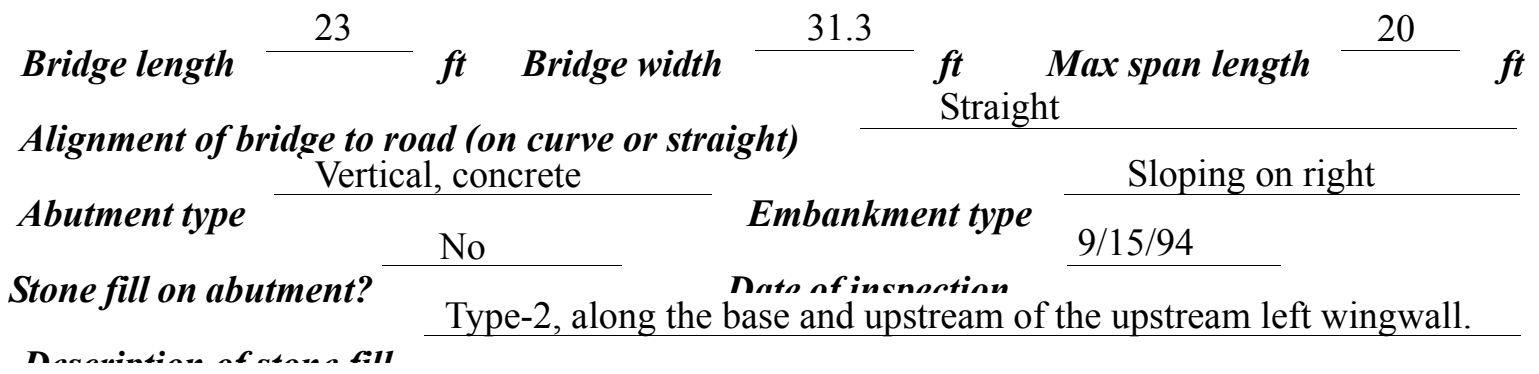

Abutments and wingwalls are concrete. There is a $2.5 \mathrm{ft}$ scour hole along left abutment.

$\overline{\mathrm{Y}}$

30

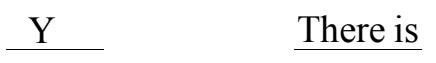

Is bridge skewed to flood flow according to a ' survey?

severe channel bend in the channel approach to the bridge. Scour has occurred in the location where the bend impacts the upstream left wingwall and abutment.

Debris accumulation on bridge at time of Level I or Level II site visit:

\begin{tabular}{|c|c|c|c|}
\hline & $\begin{array}{c}\text { Date of insnortion } \\
9 / 15 / 94 \\
\end{array}$ & $\begin{array}{l}\text { Percent of abminal } \\
\text { blocked nortzontatly }\end{array}$ & $\begin{array}{l}\text { Percent of } 0 \\
\text { blocked verticatty }\end{array}$ \\
\hline I & $9 / 15 / 94$ & -- & -- \\
\hline $\begin{array}{l}\text { Level II } \\
\text { unstrean }\end{array}$ & \multicolumn{3}{|c|}{ Low. Minor debris consisting of a couple small logs exist in the } \\
\hline
\end{tabular}

The severe channel bend concentrates most of the flow along the left abutment and may set up an Doscriho anv foaturos noar ar at tho hridoo that mav, affort flow, (includo ahsorvation dato) eddy current at the right abutment. September 15, 1994. 


\section{Description of the Geomorphic Setting}

General topography The stream is in a moderate relief, upland valley setting with irregular floodplains and steep valley walls.

Geomorphic conditions at bridge site: downstream (DS), upstream (US)

Date of inspection $\quad 9 / 15 / 94$

DS left: $\quad$ Flood plain to steep valley wall.

DS right: $\quad$ Flood plain to steep valley wall.

US left: $\quad$ Steep channel bank to high terrace and steep valley wall.

US right: $\quad$ Moderately sloping bank and flood plain.

\section{Description of the Channel}

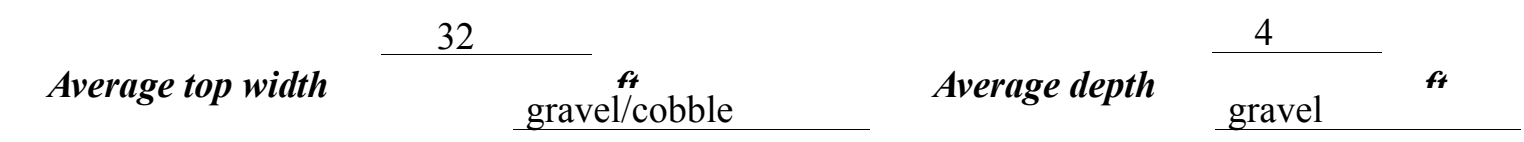

Predominant bed material

Bank material Small, sinuous,

incised channel with non-alluvial channel boundaries.

$9 / 15 / 94$

Vegetative co $^{1}$ Field grasses with gravel roadway on overbank.

DS left: $\quad$ Field grasses and some brush on immediate bank. Overbank is forested.

DS right: $\quad$ Field grasses with some brush on immediate banks.

US left: $\quad$ Field grasses with paved roadway on the overbank.

US right: $\quad$ Y

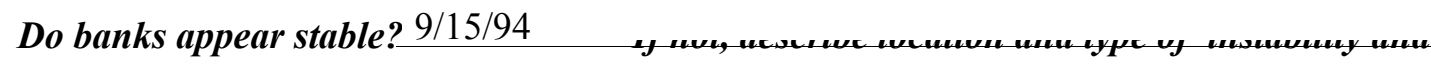

date of observatton.

None. September 15,

1994.

Describe any obstructions in channel and date of observation. 


\section{Hydrology}

Drainage area $\frac{7.98}{m_{i}{ }^{2}}$

Percentage of drainage area in physiographic provinces: (approximate)

Physiographic province/section New England/New England Upland
Percent of drainage area 100
Is drainage area considered rural or urban?
Rural None.
urbanization: None.

Is there a USGS gage on the stream of interest?

No

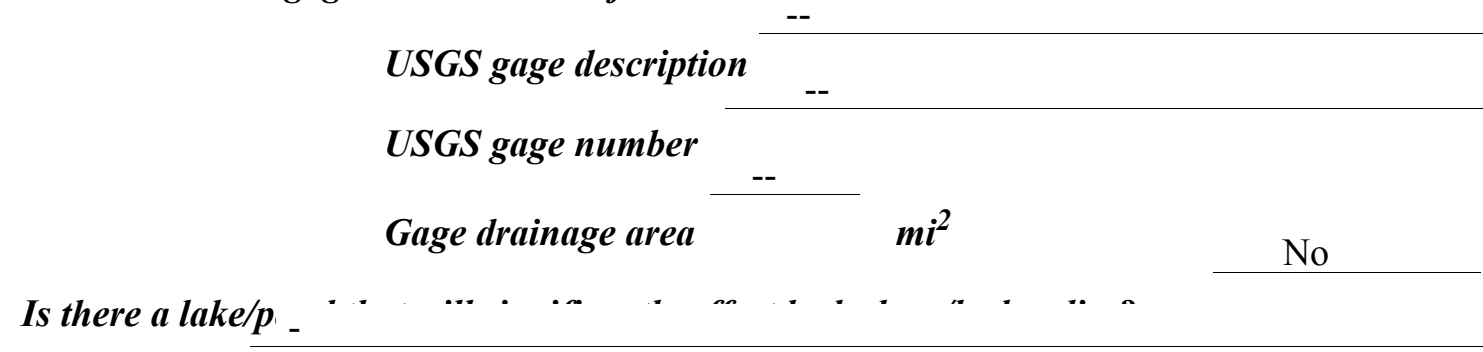

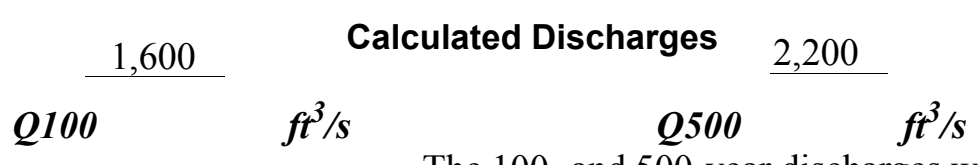

The 100- and 500-year discharges were determined

from a graphical extrapolation of available flood frequency estimates for this site in the VTAOT database (VTAOT, written communication, May, 1995). The values used were within a range defined by several empirical methods for estimating flood discharges of a given frequency (Benson, 1962; Johnson and Tasker, 1974; FHWA, 1983; Potter, 1957a\&b; Talbot, 1887). 


\section{Description of the Water-Surface Profile Model (WSPRO) Analysis}

Datum for WSPRO analysis (USGS survey, sea level, VTAOT plans)

USGS survey

Datum tie between USGS survey and VTAOT plans

Add one foot to the USGS field

survey datum to obtain the VTAOT plans' datum to the nearest foot.

Description of reference marks used to determine USGS datum. $\quad$ RM1 is the center of a

chiseled X on top of the downstream end of the left abutment (elev. $501.62 \mathrm{ft}$, arbitrary survey

datum). RM2 is the center of a chiseled $\mathrm{X}$ on top of the upstream end of the right abutment

(elev. $501.80 \mathrm{ft}$, arbitrary survey datum).

\section{Cross-Sections Used in WSPRO Analysis}

\begin{tabular}{|c|c|c|c|}
\hline${ }^{1}$ Cross-section & $\begin{array}{c}\text { Section } \\
\text { Reference } \\
\text { Distance } \\
\text { (SRD) in feet }\end{array}$ & $\begin{array}{c}{ }^{2} \text { Cross-section } \\
\text { development }\end{array}$ & Comments \\
\hline EXITX & -34 & 1 & Exit section \\
\hline FULLV & 0 & 2 & $\begin{array}{l}\text { Downstream Full-valley } \\
\text { section (Templated from } \\
\text { EXITX) }\end{array}$ \\
\hline BRIDG & 0 & 1 & Bridge section \\
\hline RDWAY & 17 & 1 & Road Grade section \\
\hline APPRO & 54 & 2 & $\begin{array}{l}\text { Modelled Approach sec- } \\
\text { tion (Templated from } \\
\text { APTEM) }\end{array}$ \\
\hline APTEM & 114 & 1 & $\begin{array}{l}\text { Approach section as sur- } \\
\text { veyed (Used as a tem- } \\
\text { plate) }\end{array}$ \\
\hline
\end{tabular}

${ }^{1}$ For location of cross-sections see plan-view sketch included with Level I field form, Appendix E.

For more detail on how cross-sections were developed see WSPRO input file. 


\section{Data and Assumptions Used in WSPRO Model}

Hydraulic analyses of the reach were done by use of the Federal Highway Administration's WSPRO step-backwater computer program (Shearman and others, 1986, and Shearman, 1990). The analyses reported herein reflect conditions existing at the site at the time of the study. Furthermore, in the development of the model it was necessary to assume no accumulation of debris or ice at the site. Results of the hydraulic model are presented in the Bridge Hydraulic Summary, Appendix B, and figure 7.

Channel roughness factors (Manning's “ $n$ ”) used in the hydraulic model were estimated using field inspections at each cross section following the general guidelines described by Arcement and Schneider (1989). Final adjustments to the values were made during the modelling of the reach. The channel " $n$ " value for the reach was 0.040 . Overbank " $n$ " values ranged from 0.035 to 0.080 .

Normal depth at the exit section (EXITX) was assumed as the starting water surface. This depth was computed by use of the slope-conveyance method outlined in the user's manual for WSPRO (Shearman, 1990). The slope used was $0.0063 \mathrm{ft} / \mathrm{ft}$ which was estimated from the topographic map (U.S. Geological Survey, 1966).

The surveyed approach section (APTEM) was moved along the approach channel slope $(0.014 \mathrm{ft} / \mathrm{ft})$ to establish the modelled approach section (APPRO), one bridge length upstream of the upstream face as recommended by Shearman and others (1986). This approach also provides a consistent method for determining scour variables.

Both the 100- and 500-year discharges overtopped the roadway. The incipient road overtopping discharge is $760 \mathrm{cfs}$. 


\section{Bridge Hydraulics Summary}

$\begin{array}{llll}\text { Average bridge embankment elevation } & 502.2 & f t \\ \text { Average low steel elevation } & 500.3 & \boldsymbol{f t}\end{array}$

100-year discharge $\quad 1,600 \quad \mathrm{ft}^{3} / \mathrm{s}$

Water-surface elevation in bridge opening $\quad 500.3 f t$

Road overtopping? __ Y Discharge over road _ $\quad 519, \ldots$

\begin{tabular}{llcl} 
Area of flow in bridge opening & $113 \quad \boldsymbol{f t}^{2}$ \\
\cline { 2 - 3 } Average velocity in bridge opening & $9.8 \quad \mathrm{ft} / \mathrm{s}$
\end{tabular}

Maximum WSPRO tube velocity at bridge $11.8 \mathrm{ft} / \mathrm{s}$

Water-surface elevation at Approach section with bridge 502.6

Water-surface elevation at Approach section without bridge $\quad 500.9$

Amount of backwater caused by bridge

$1.7, i$

500-year discharge $\quad 2,200 \quad \mathrm{ft}^{3} / \mathrm{s}$

Water-surface elevation in bridge opening $\quad 500.3 \mathrm{ft}$

Road overtopping? ___ Y Discharge over road

$1170^{-}$

Area of flow in bridge opening

Average velocity in bridge opening

113 $f t^{2}$

Maximum WSPRO tube velocity at bridge

93

$f t / s$

11.2 .5

Water-surface elevation at Approach section with bridge

Water-surface elevation at Approach section without bridge

503.2

Amount of backwater caused by bridge

1.6

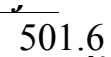

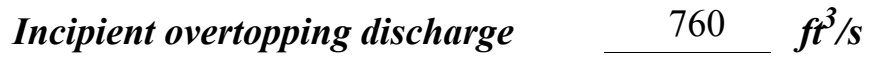

Water-surface elevation in bridge opening $500.3 \quad t$

Area of flow in bridge opening

$113 \quad \mathrm{ft}^{2}$

Average velocity in bridge opening

Maximum WSPRO tube velocity at bridge

6.8 $f t / s$

Water-surface elevation at Approach section with bridge

Water-surface elevation at Approach section without bridge

501.2

Amount of backwater caused by bridge 1.8 . $t$ 


\section{Scour Analysis Summary}

\section{Special Conditions or Assumptions Made in Scour Analysis}

Scour depths were computed using the general guidelines described in Hydraulic Engineering Circular 18 (Richardson and others, 1995). Scour depths were calculated assuming an infinite depth of erosive material and a homogeneous particle-size distribution. The results of the scour analysis are presented in tables 1 and 2 and a graph of the scour depths is presented in figure 8 .

Contraction scour was computed by use of the Chang pressure-flow scour equation (Richardson and others, 1995, p. 145-146) for the 100-year, 500-year and incipient overtopping discharges. For all of the modelled discharges, there was orifice flow at the bridge. Contraction scour at bridges with orifice flow is best estimated by use of the Chang pressure-flow scour equation (oral communication, J. Sterling Jones, October 4, 1996). The results of Laursen's clearwater contraction scour equation (Richardson and others, 1995, p. 32, equation 20) were also computed for the 100-year and 500-year discharges and can be found in appendix F.

In this case, the 100-year model resulted in the worst case contraction scour with a scour depth of $1.5 \mathrm{ft}$. It was also the worst case total scour. The depths to armoring indicate that armoring will not limit the amount of contraction scour.

Abutment scour was computed by use of the Froehlich equation (Richardson and others, 1995, p. 48, equation 28). Variables for the Froehlich equation include the Froude number of the flow approaching the embankments, the length of the embankment blocking flow, and the depth of flow approaching the embankment less any roadway overtopping.

The length to depth ratio of the embankment blocking flow exceeded 25 for the 100-and 500-year discharges at the right abutment. Although the HIRE equation (Richardson and others, 1993 , p. 50, equation 25) generally is applicable when this ratio exceeds 25 , the results from the HIRE equation were not used. Hydraulic Engineering Circular 18 recommends that the field conditions should be similar to those from which the HIRE equation was derived (Richardson and others, 1993). Since the equation was developed from Army Corp. of Engineers' data obtained for spurs dikes in the Mississippi River, the HIRE equation was not adopted for the narrow, incised, upland valley at this site. 


\section{Scour Results}

\section{0-yr discharge 500-yr discharge}

Contraction scour:

(Scour depths in feet)

Main channel

Live-bed scour

Clear-water scour

Depth to armoring

Left overbank

Right overbank

Local scour:

Abutment scour

Left abutment

9.1

9.2

7.2

$12.1-$

$12.6-$

$10.0-$

Right abutment

Pier scour

Pier 1

Pier 2

Pier 3

\section{Abutments:}

Left abutment

Right abutment

Piers:

Pier 1

Pier 2

overtopping discharge 


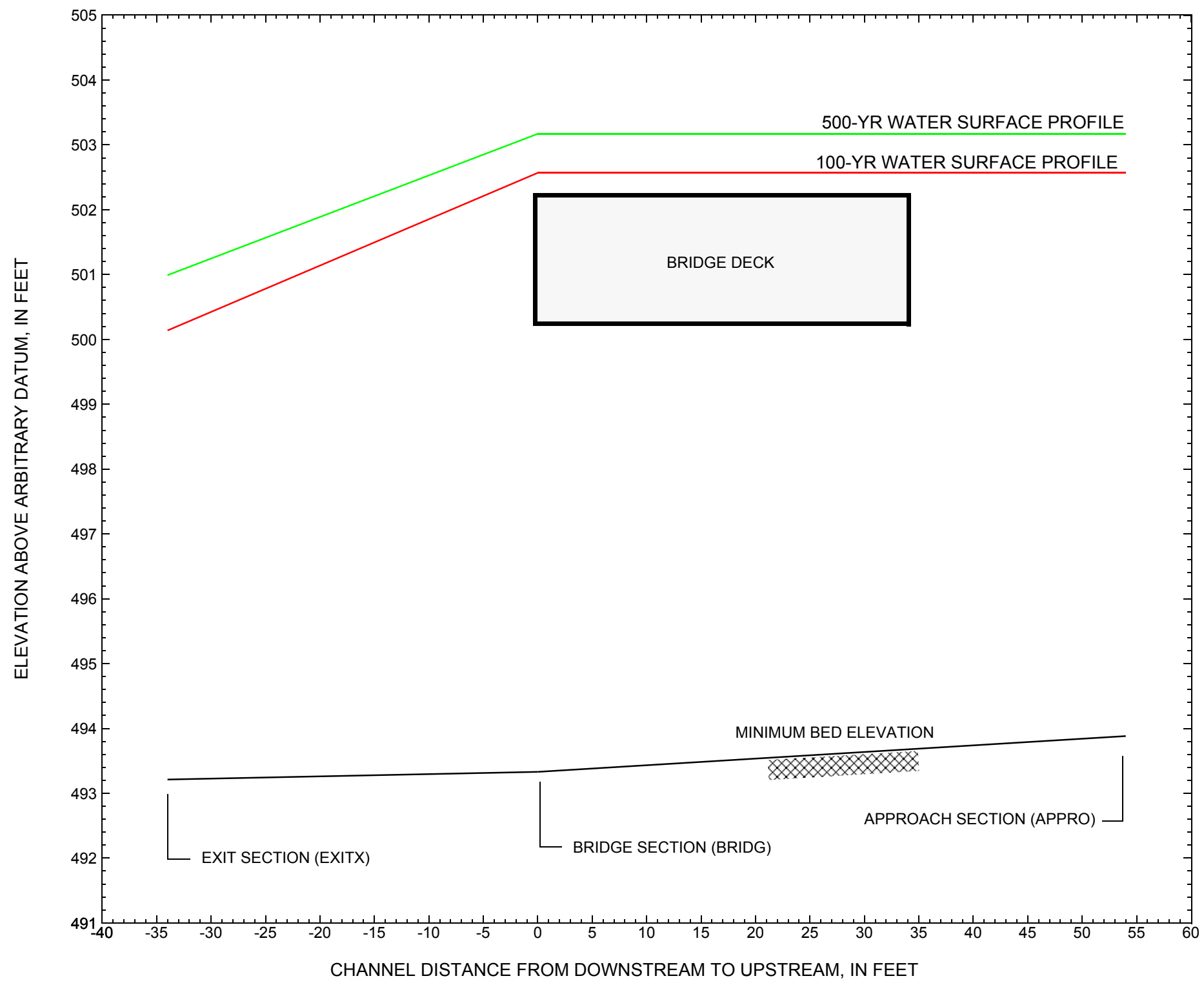

Figure 7. Water-surface profiles for the 100- and 500-yr discharges at structure POMFTH00020013 on town highway 2, crossing Barnard Brook, Pomfret, Vermont. 


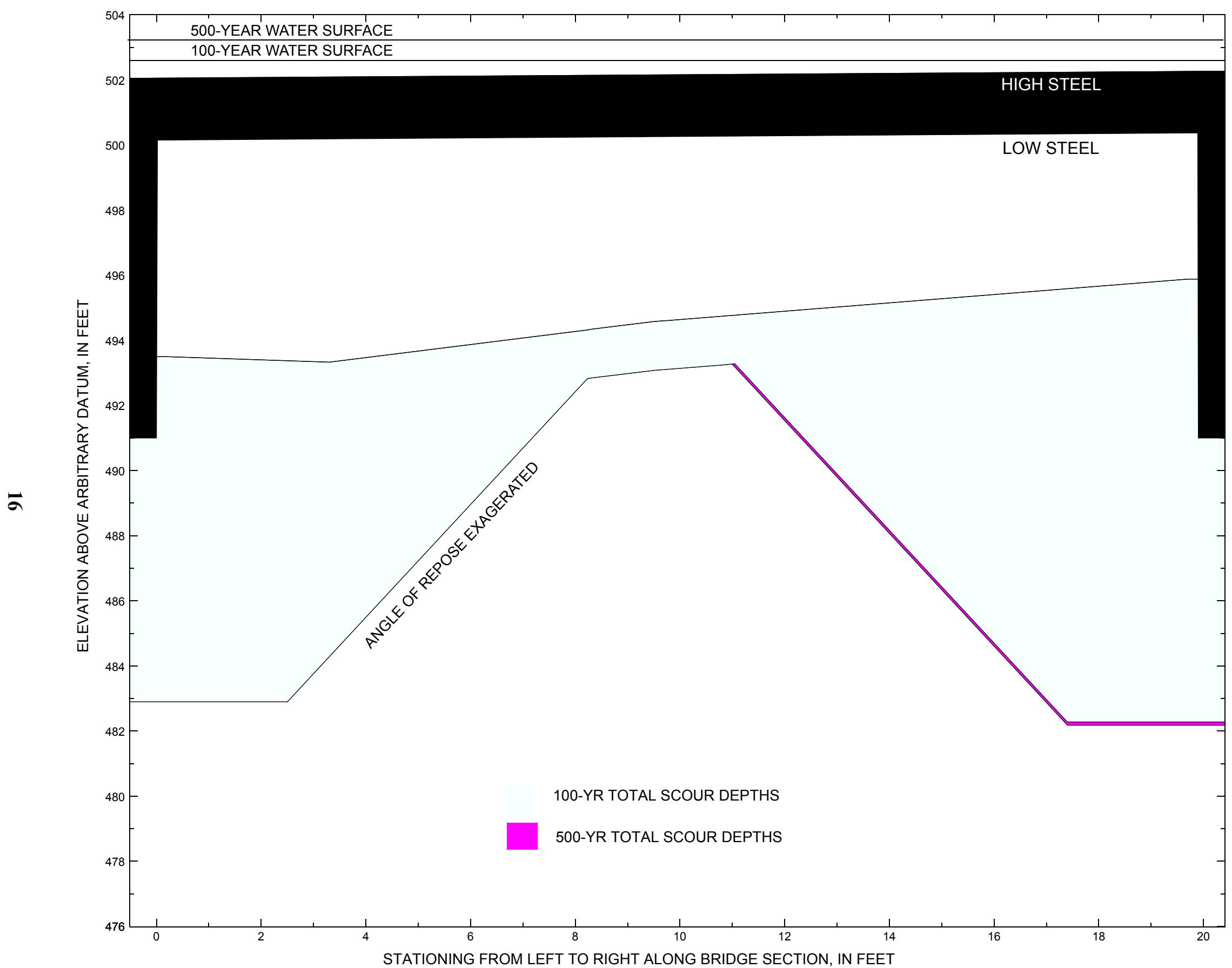

Figure 8. Scour elevations for the 100-yr and 500-yr discharges at structure POMFTH00020013 on town highway 2, crossing Barnard Brook, Pomfret, Vermont. 
Table 1. Remaining footing/pile depth at abutments for the 100-year discharge at structure POMFTH00020013 on Town Highway 2, crossing Barnard Brook, Pomfret, Vermont.

[VTAOT, Vermont Agency of Transportation; --,no data]

\begin{tabular}{|c|c|c|c|c|c|c|c|c|c|c|c|}
\hline Description & Station $^{1}$ & $\begin{array}{c}\text { VTAOT } \\
\text { bridge seat } \\
\text { elevation } \\
\text { (feet) }\end{array}$ & $\begin{array}{l}\text { Surveyed } \\
\text { minimum } \\
\text { low-chord } \\
\text { elevation }{ }^{2} \\
\text { (feet) }\end{array}$ & $\begin{array}{c}\text { Bottom of } \\
\text { footing } \\
\text { elevation } \\
\text { (feet) }\end{array}$ & $\begin{array}{c}\text { Channel } \\
\text { elevation at } \\
\text { abutment/ } \\
\text { pier }^{2} \\
\text { (feet) }\end{array}$ & $\begin{array}{l}\text { Contraction } \\
\text { scour depth } \\
\text { (feet) }\end{array}$ & $\begin{array}{l}\text { Abutment } \\
\text { scour } \\
\text { depth } \\
\text { (feet) }\end{array}$ & $\begin{array}{l}\text { Pier } \\
\text { scour } \\
\text { depth } \\
\text { (feet) }\end{array}$ & $\begin{array}{l}\text { Depth of } \\
\text { total scour } \\
\text { (feet) }\end{array}$ & $\begin{array}{c}\text { Elevation of } \\
\text { scour }^{2} \\
\text { (feet) }\end{array}$ & $\begin{array}{c}\text { Remaining } \\
\text { footing/pile } \\
\text { depth } \\
\text { (feet) }\end{array}$ \\
\hline \multicolumn{12}{|c|}{100 -yr. discharge is 1,600 cubic-feet per second } \\
\hline Left abutment & 0.0 & 500.70 & 500.17 & 490 & 493.5 & 1.5 & 9.1 & -- & 10.6 & 482.9 & -7 \\
\hline Right abutment & 19.9 & 500.94 & 500.33 & 490 & 495.9 & 1.5 & 12.1 & -- & 13.6 & 482.3 & -8 \\
\hline
\end{tabular}

1. Measured along the face of the most constricting side of the bridge.

2. Arbitrary datum for this study.

Table 2. Remaining footing/pile depth at abutments for the 500-year discharge at structure POMFTH00020013 on Town Highway 2, crossing Barnard Brook, Pomfret, Vermont.

[VTAOT, Vermont Agency of Transportation; --, no data]

\begin{tabular}{|c|c|c|c|c|c|c|c|c|c|c|c|}
\hline Description & Station $^{1}$ & $\begin{array}{c}\text { VTAOT } \\
\text { bridge seat } \\
\text { elevation } \\
\text { (feet) }\end{array}$ & $\begin{array}{l}\text { Surveyed } \\
\text { minimum } \\
\text { low-chord } \\
\text { elevation }{ }^{2} \\
\text { (feet) }\end{array}$ & $\begin{array}{l}\text { Bottom of } \\
\text { footing } \\
\text { elevation } \\
\text { (feet) }\end{array}$ & $\begin{array}{c}\text { Channel } \\
\text { elevation at } \\
\text { abutment/ } \\
\text { pier }^{2} \\
\text { (feet) }\end{array}$ & $\begin{array}{l}\text { Contraction } \\
\text { scour depth } \\
\text { (feet) }\end{array}$ & $\begin{array}{l}\text { Abutment } \\
\text { scour } \\
\text { depth } \\
\text { (feet) }\end{array}$ & $\begin{array}{l}\text { Pier } \\
\text { scour } \\
\text { depth } \\
\text { (feet) }\end{array}$ & $\begin{array}{l}\text { Depth of } \\
\text { total scour } \\
\text { (feet) }\end{array}$ & $\begin{array}{c}\text { Elevation of } \\
\text { scour }^{2} \\
\text { (feet) }\end{array}$ & $\begin{array}{c}\text { Remaining } \\
\text { footing/pile } \\
\text { depth } \\
\text { (feet) }\end{array}$ \\
\hline \multicolumn{12}{|c|}{500 -yr. discharge is 2,200 cubic-feet per second } \\
\hline Left abutment & 0.0 & 500.70 & 500.17 & 490 & 493.5 & 1.1 & 9.2 & -- & 10.3 & 483.2 & -7 \\
\hline Right abutment & 19.9 & 500.94 & 500.33 & 490 & 495.9 & 1.1 & 12.6 & -- & 13.7 & 482.2 & -8 \\
\hline
\end{tabular}

1. Measured along the face of the most constricting side of the bridge.

2. Arbitrary datum for this study. 


\section{SELECTED REFERENCES}

Arcement, G.J., Jr., and Schneider, V.R., 1989, Guide for selecting Manning's roughness coefficients for natural channels and flood plains: U.S. Geological Survey Water-Supply Paper 2339, 38 p.

Barnes, H.H., Jr., 1967, Roughness characteristics of natural channels: U.S. Geological Survey Water-Supply Paper 1849,213 p.

Benson, M. A., 1962, Factors Influencing the Occurrence of Floods in a Humid Region of Diverse Terrain: U.S. Geological Survey WaterSupply Paper 1580-B, 64 p.

Brown, S.A. and Clyde, E.S., 1989, Design of riprap revetment: Federal Highway Administration Hydraulic Engineering Circular No. 11, Publication FHWA-IP-89-016, 156 p.

Federal Highway Administration, 1983, Runoff estimates for small watersheds and development of sound design: Federal Highway Administration Report FHWA-RD-77-158

Froehlich, D.C., 1989, Local scour at bridge abutments in Ports, M.A., ed., Hydraulic Engineering--Proceedings of the 1989 National Conference on Hydraulic Engineering: New York, American Society of Civil Engineers, p. 13-18.

Hayes, D.C.,1993, Site selection and collection of bridge-scour data in Delaware, Maryland, and Virginia: U.S. Geological Survey WaterResources Investigation Report 93-4017, 23 p.

Johnson, C.G. and Tasker, G.D.,1974, Progress report on flood magnitude and frequency of Vermont streams: U.S. Geological Survey OpenFile Report 74-130, 37 p.

Lagasse, P.F., Schall, J.D., Johnson, F., Richardson, E.V., Chang, F., 1995, Stream Stability at Highway Structures: Federal Highway Administration Hydraulic Engineering Circular No. 20, Publication FHWA-IP-90-014, 144 p.

Laursen, E.M., 1960, Scour at bridge crossings: Journal of the Hydraulics Division, American Society of Civil Engineers, v. 86, no. HY2, p. 39-53.

Potter, W. D., 1957a, Peak rates of runoff in the Adirondack, White Mountains, and Maine woods area, Bureau of Public Roads

Potter, W. D., 1957b, Peak rates of runoff in the New England Hill and Lowland area, Bureau of Public Roads

Richardson, E.V. and Davis, S.R., 1995, Evaluating scour at bridges: Federal Highway Administration Hydraulic Engineering Circular No. 18, Publication FHWA-IP-90-017, 204 p.

Richardson, E.V., Simons, D.B., and Julien, P.Y., 1990, Highways in the river environment: Federal Highway Administration Publication FHWA-HI-90-016.

Ritter, D.F., 1984, Process Geomorphology: W.C. Brown Co., Debuque, Iowa, 603 p.

Shearman, J.O., 1990, User's manual for WSPRO--a computer model for water surface profile computations: Federal Highway Administration Publication FHWA-IP-89-027, 187 p.

Shearman, J.O., Kirby, W.H., Schneider, V.R., and Flippo, H.N., 1986, Bridge waterways analysis model; research report: Federal Highway Administration Publication FHWA-RD-86-108, 112 p.

Talbot, A.N., 1887, The determination of water-way for bridges and culverts.

U.S. Department of Transportation, 1993, Stream stability and scour at highway bridges, Participant Workbook: Federal Highway Administration Publication FHWA HI-91-011.

U.S. Geological Survey, 1966, Woodstock North, Vermont 7.5 Minute Series quadrangle map: U.S. Geological Survey Topographic Maps, Scale 1:24,000. 


\section{APPENDIX A: \\ WSPRO INPUT FILE}




\section{WSPRO INPUT FILE}

*

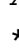

\section{*}

BR

GR

GR

*

*

$\mathrm{CD}$

$\mathrm{N}$

*

*

$\mathrm{XR}$

GR

GR

GR

*

$X T$

GR

GR

GR

GR

*

AS

N

SA

*

HP 1 BRIDG

HP 2 BRIDG

HP 2 RDWAY

HP 1 APPRO

HP 2 APPRO

*

HP 1 BRIDG

HP 2 BRIDG

HP 2 RDWAY

HP 1 APPRO

HP 2 APPRO
U.S. Geological Survey WSPRO Input File pomf013.wsp Hydraulic analysis for structure POMFTH00020013 Date: 03-MAY-96 Hydraulic Analysis for Pomfret bridge 13 over Barnard Brook by MAI $1600.0 \quad 2200.0 \quad 760.0$

$0.0063 \quad 0.0063 \quad 0.0063$

$\begin{array}{lllllllllllllllllllll}6 & 29 & 30 & 552 & 553 & 551 & 5 & 16 & 17 & 13 & 3 & * & 15 & 14 & 23 & 21 & 11 & 12 & 4 & 7 & 3\end{array}$ $\operatorname{EXITX} \quad-34$

\begin{tabular}{|c|c|c|c|c|c|c|c|}
\hline-119.3 & 501.30 & -97.9, & 500.50 & -79.8, & 501.22 & -58.3, & 500.64 \\
\hline-14.1 & 497.20 & -6.0, & 496.88 & 0.0 , & 494.22 & 1.2, & 493.36 \\
\hline 3.0 & 493.21 & 10.9, & 494.14 & 13.3, & 494.72 & 14.8, & 495.94 \\
\hline 21.6, & 498.22 & 57.7, & 499.54 & 99.1 , & 501.10 & 109.5 , & 504.7 \\
\hline 0.035 & & & 0.080 & & & & \\
\hline
\end{tabular}

$-6.0-14.8$

$0 * * * 0.0034$

SRD LSEL XSSKEW

$0 \quad 500.25 \quad 0.0$

$0.0,500.17 \quad 0.2,493.50$

$3.3,493.33$

$9.5,494.58$

$19.7,495.88$

$19.9,500.33$

$0.0,500.17$

BRTYPE BRWDTH WWANGL WWWID

$142.3 * * \quad 58.4 \quad 4.9$

0.040

$\begin{array}{rrr}\text { SRD } & \text { EMBWID } & \text { IPAVE } \\ 17 & 31.3 & 1\end{array}$

$20.4,502.27$

$-47.9, \quad 501.22$

$-29.8,501.50$

$0.0,502.05$

$202.1,505.89$

$23.7,502.30$

$60.6,502.67$

$123.3,503.58$

114

$-22.0,506.10$

$-15.8,503.35$

$0.0,495.73$

$0.3,495.30$

$4.4,494.72$

$12.9,495.61$

$12.9,495.61$

$26.2,497.66$

$32.9,498.93$

$43.5,499.00$

$49.9,502.29$

$56.6,502.98$
$171.9,505.9$

$54 * * * 0.014$

0.035

$-15.8$

0.040

26.2

500.331500 .33

$500.33 * * 1107$

$502.57 * * 519$

502.571502 .57

$502.57 * * 1600$

500.331500 .33

$500.33 * * 1051$

$503.17 * * 1168$

503.171503 .17

$503.17 * * 2200$ 


\section{APPENDIX B: \\ WSPRO OUTPUT FILE}




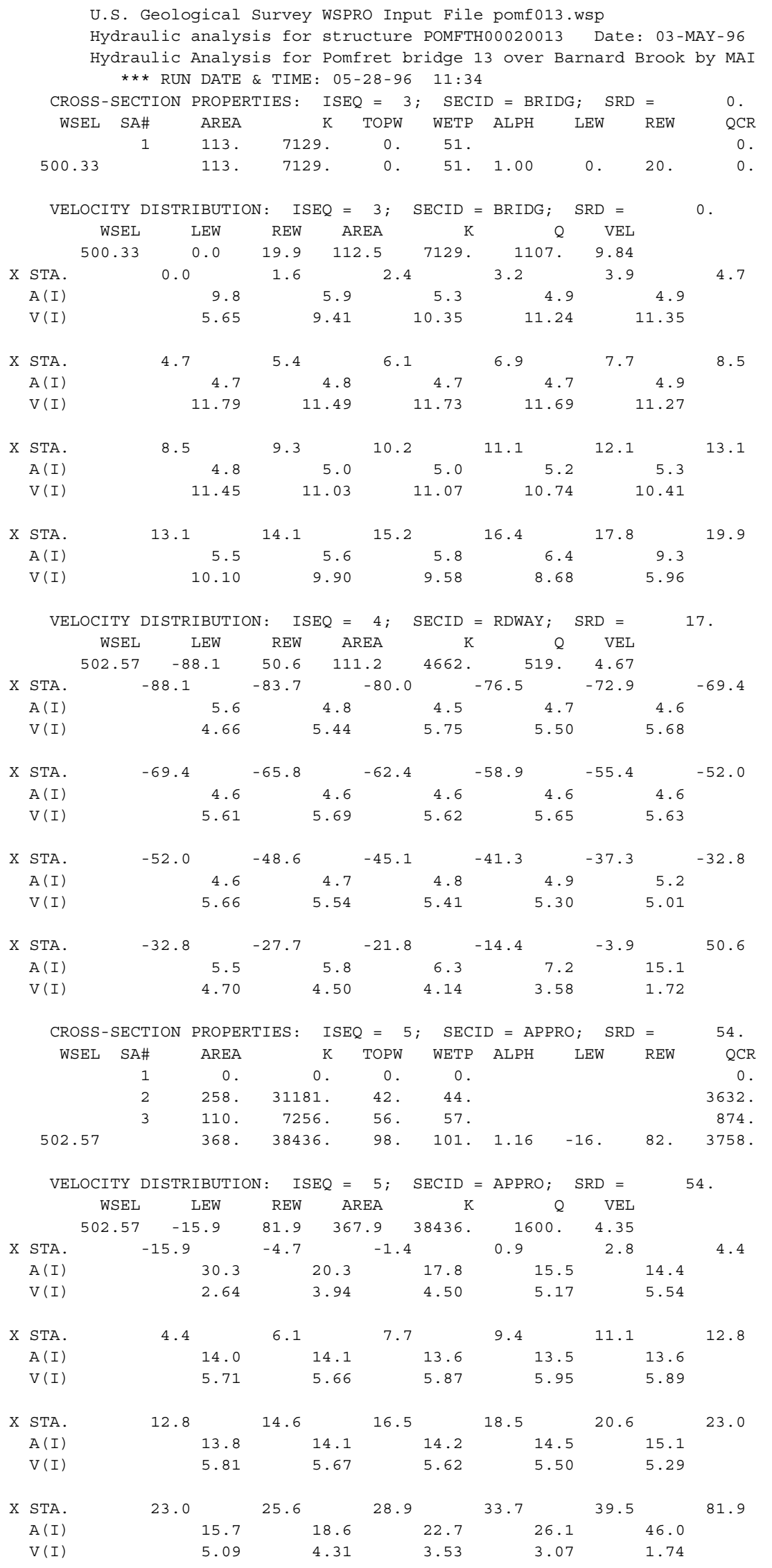


WSPRO OUTPUT FILE (continued)

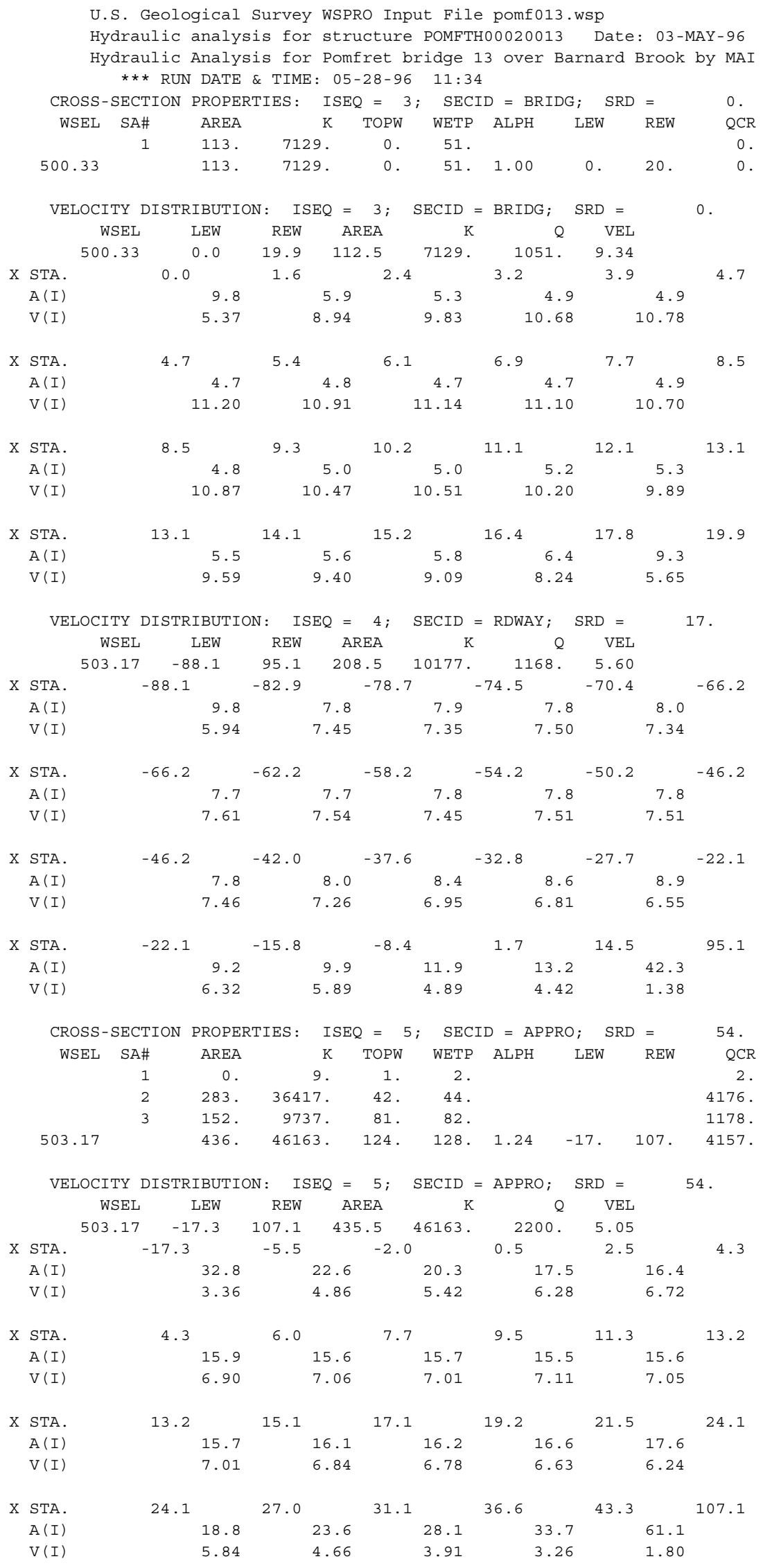


WSPRO OUTPUT FILE (continued)

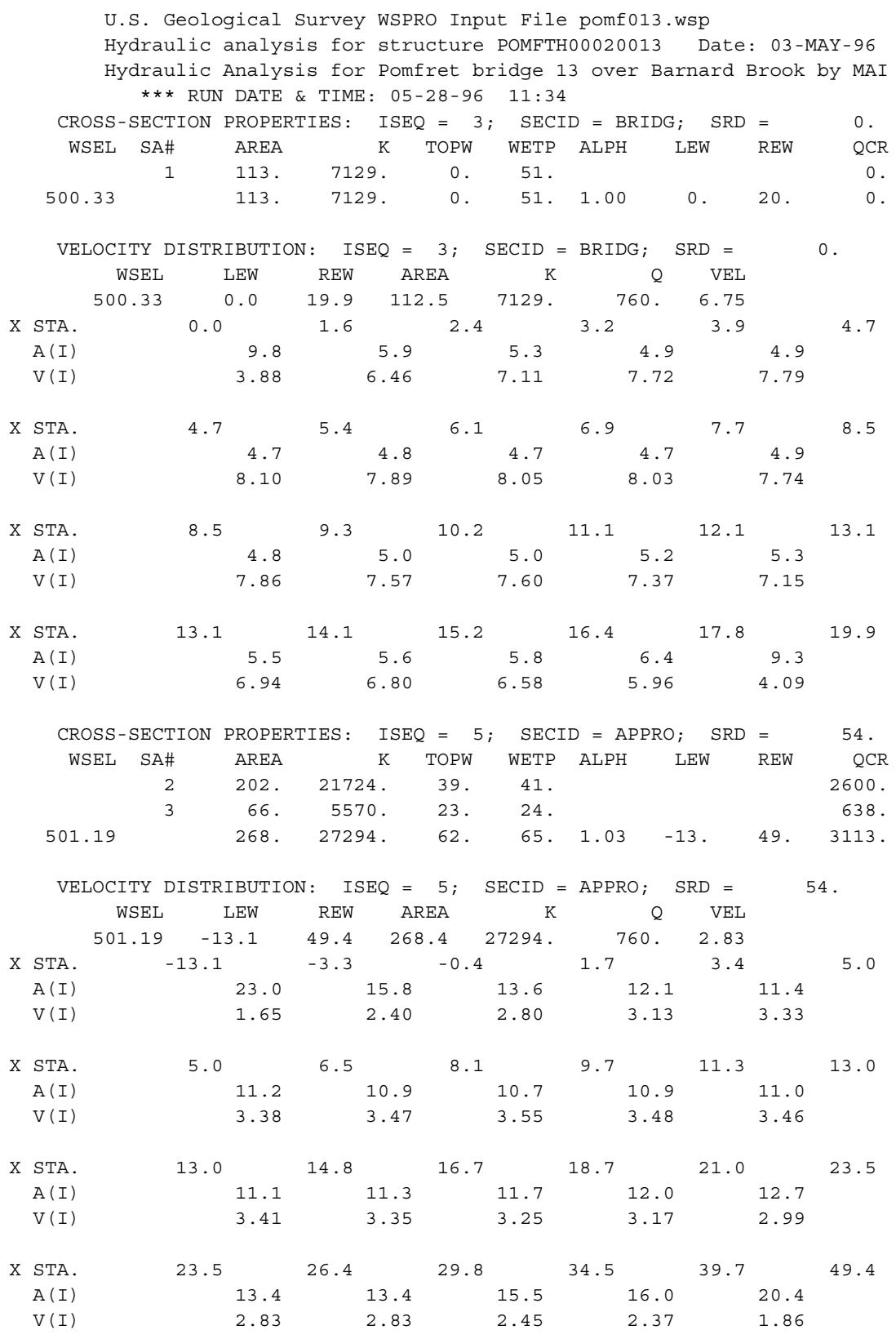


WSPRO OUTPUT FILE (continued)

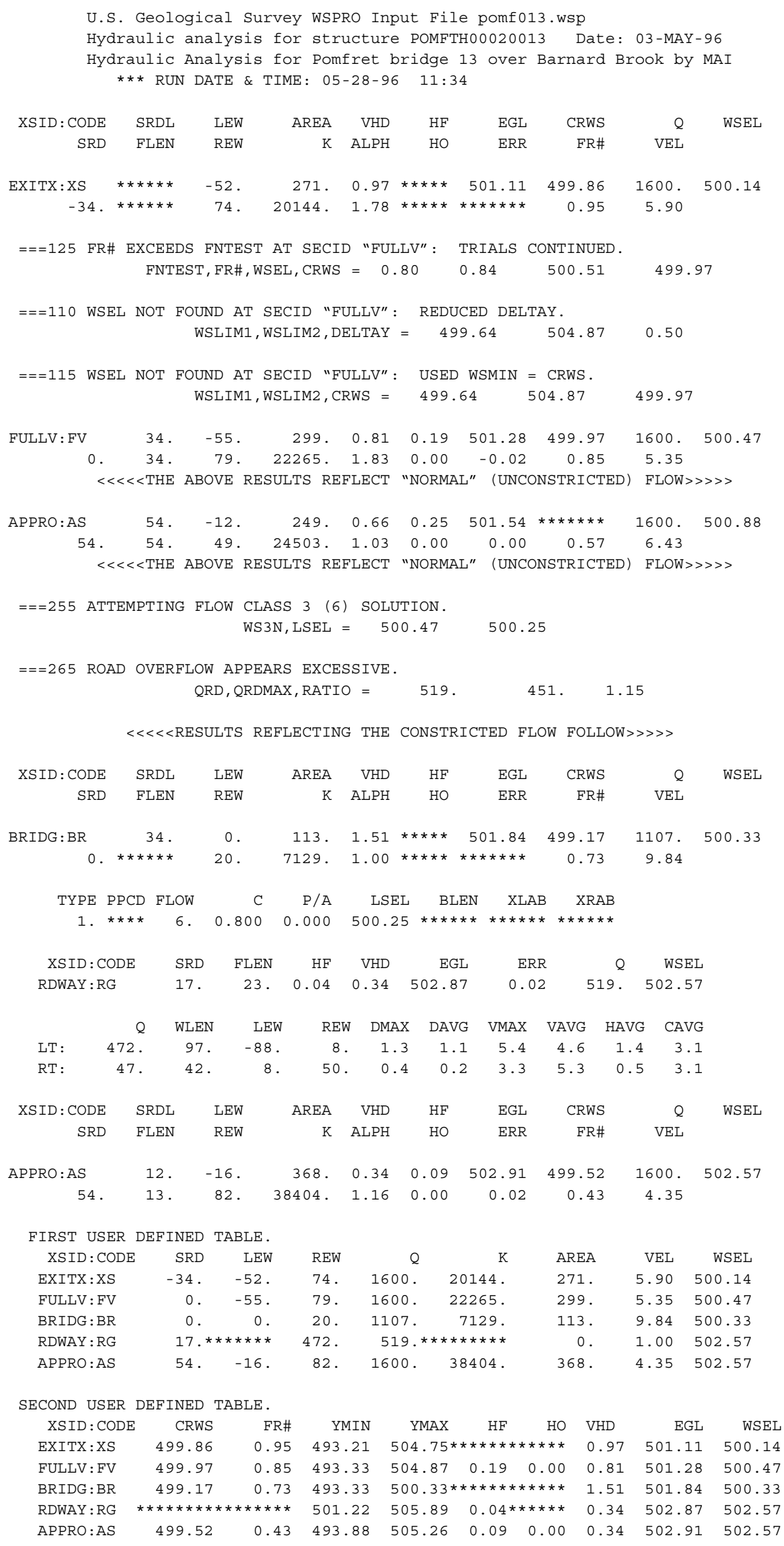


WSPRO OUTPUT FILE (continued)

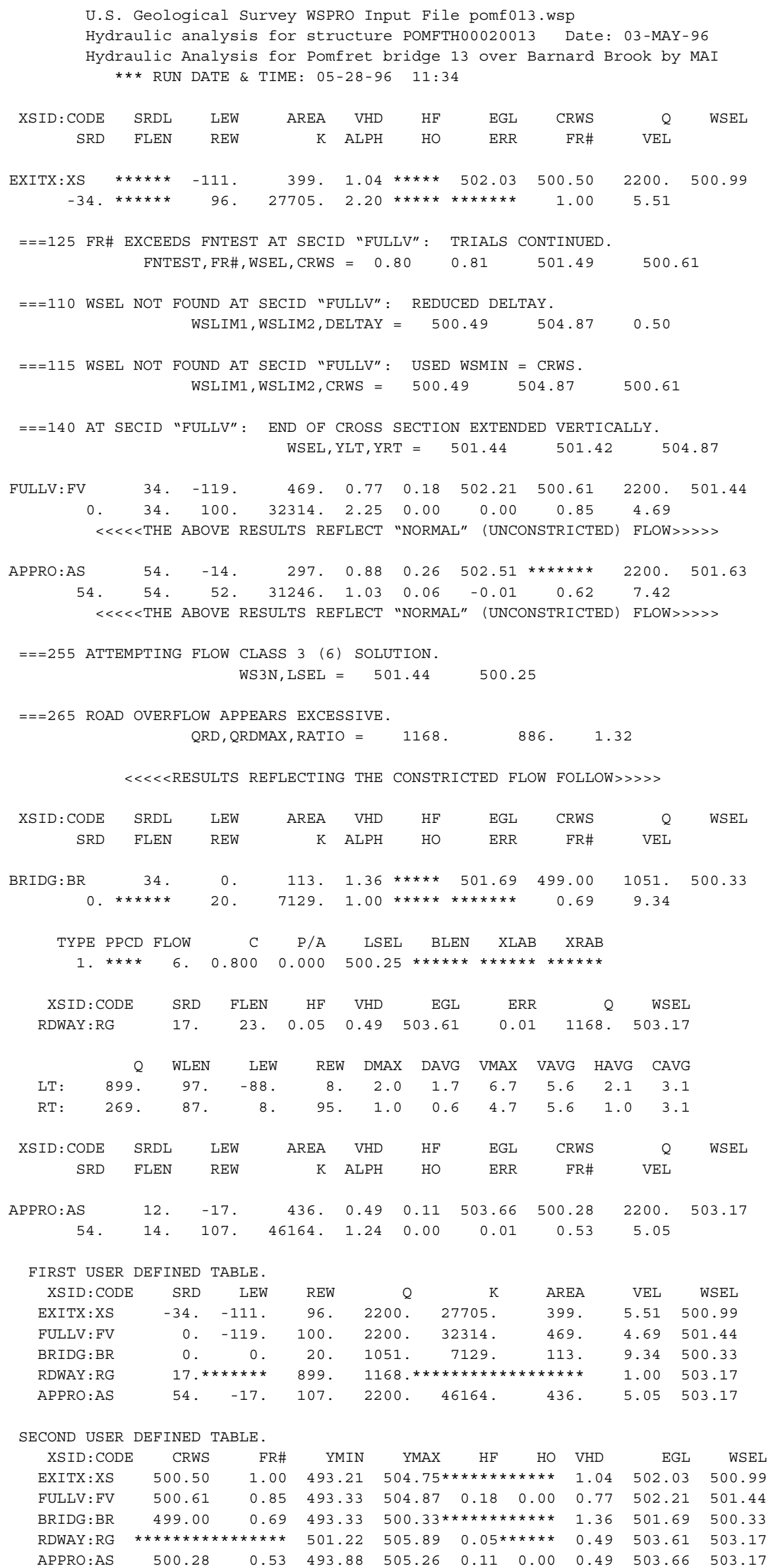


WSPRO OUTPUT FILE (continued)

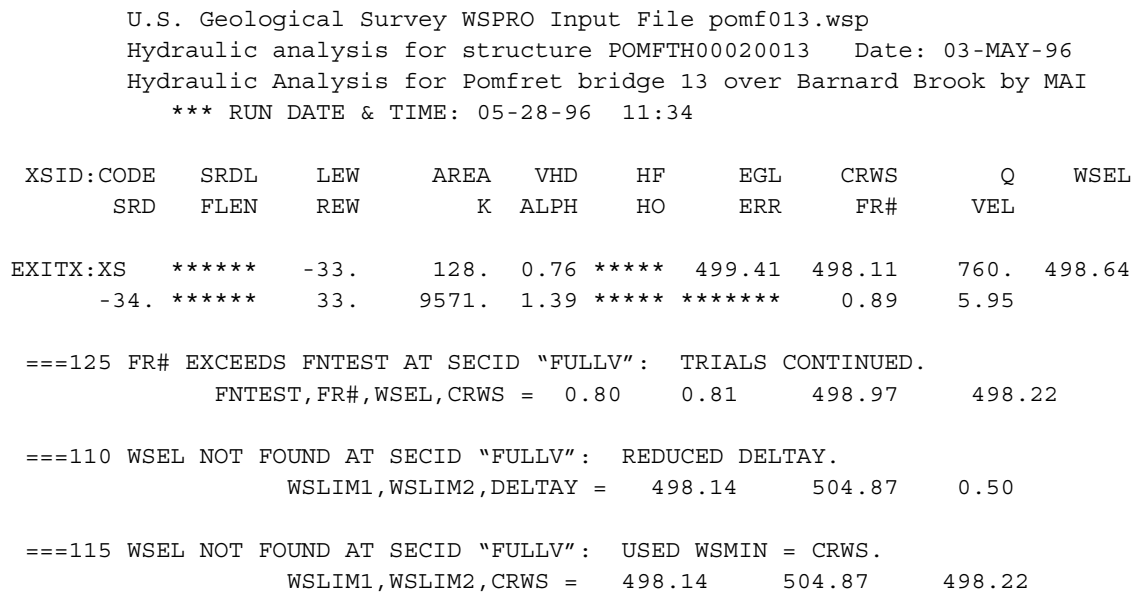




\section{APPENDIX C:}

\section{BED-MATERIAL PARTICAL-SIZE DISTRIBUTION}




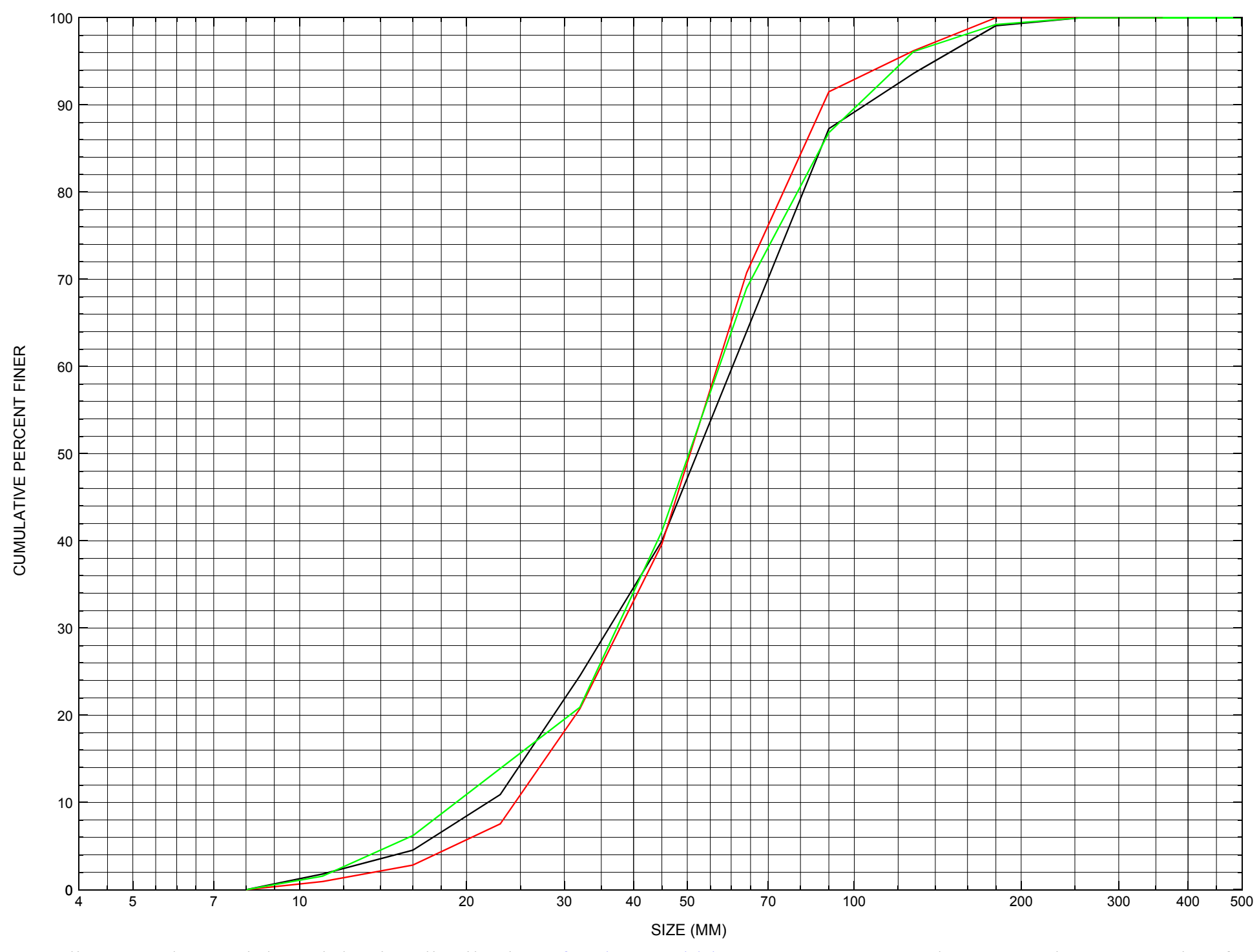

Appendix C. Bed material particle-size distributions for three pebble count transects at the approach cross-section for structure POMFTH00020013, in Pomfret, Vermont. 


\section{APPENDIX D: \\ HISTORICAL DATA FORM}




\section{Structure Number POMFTH00020013}

\section{General Location Descriptive}

Data collected by (First Initial, Full last name) $\mathbf{E}$. BOEHMLER

Date $(M M / D D / Y Y) \_\mathbf{0 8} / \underline{\mathbf{2 2}} / \underline{\mathbf{9 4}}$

Highway District Number (I - 2; nn) $\mathbf{0 4}$

Town (FIPS place code; I - 4; nnnnn) $\mathbf{5 6 3 5 0}$

Waterway (I - 6) BARNARD BROOK

Route Number $\underline{\text { TH002 }}$

Topographic Map Woodstock.North

Latitude (I - 16; nnnn.n) $\mathbf{4 3 4 0 2}$
County (FIPS county code; I - 3; nnn)

Mile marker (I - 11; nnn.nnn) $\mathbf{0 0 0 0 0 0}$

Road Name (I - 7): -

Vicinity (I - 9) 0.5 MI JCT TH $2+$ TH 1

Hydrologic Unit Code: $\mathbf{0 1 0 8 0 1 0 6}$

Longitude (i - 17; nnnnn.n) $\mathbf{7 2 3 2 8}$

\section{Select Federal Inventory Codes}

FHWA Structure Number (I - 8) 10141300131413

Maintenance responsibility $(I-21 ; n n) \quad \mathbf{0 3} \quad$ Maximum span length $(I-48 ; n n n n) \underline{\mathbf{0 0 2 0}}$

Year built (I - 27; YYYY) 1972

Structure length (I - 49; nnnnnn) $\underline{\mathbf{0 0 0 0 2 3}}$

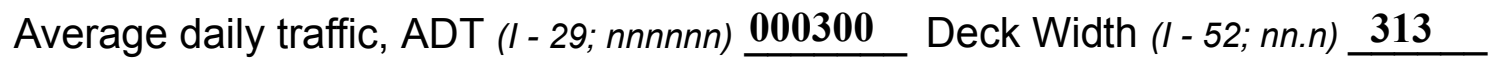

Year of ADT (I - 30; YY) $\mathbf{9 0}$

Channel \& Protection $(I-61 ; n) \underline{\mathbf{6}}$

Opening skew to Roadway $(I-34 ; n n) \quad \mathbf{0 0}$

Waterway adequacy $(I-71 ; n) \quad 5$

Operational status $(I-41 ; X)$ A

Underwater Inspection Frequency $(I-92 B ; X Y Y) \_\mathbf{N}$

Structure type (I - 43; nnn) 101

Year Reconstructed (I - 106) $\mathbf{0 0 0 0}$

Approach span structure type (I - 44; nnn) $\mathbf{0 0 0}$ Clear span $(n n n . n f t)$

Number of spans (I - 45; nnn) $\mathbf{0 0 1}$

Vertical clearance from streambed (nnn.n ft) $\underline{\mathbf{0 0 5 . 0}}$

Number of approach spans (I - 46; nnnn) $\mathbf{0 0 0 0}$

Waterway of full opening $\left(n n n . n \mathrm{ft}^{2}\right)$

Comments:

Structural inspection report of 6/22/94 indicates abutment concrete walls look new. Footings are not visible at the surface. The inspection indicated no channel scour or road embankment erosion. A mid-channel sand bar is noted along the right abutment. The channel is noted as making a sharp bend into the bridge crossing. Stone fill was present and in good condition. 


\section{Bridge Hydrologic Data}

Is there hydrologic data available? $\underline{\mathbf{N}}$ if No, type ctrl-n $h \quad$ VTAOT Drainage area $\left(m i^{2}\right)$ : -

Terrain character:

Stream character \& type: -

Streambed material: Mud and gravel

Discharge Data (cfs): $\quad Q_{2.33}-$

$$
\mathrm{Q}_{50}-
$$

Record flood date (MM / DD / YY): -

Estimated Discharge (cfs): I

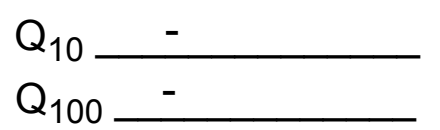

$\mathrm{Q}_{25}-$

Water surface elevation $(f t):-$

Ice conditions (Heavy, Moderate, Light) : -

Velocity at $\mathrm{Q}$ $(\mathrm{ft} / \mathrm{s}):$

The stage increases to maximum highwater elevation (Rapidly, Not rapidly):

The stream response is (Flashy, Not flashy):

Describe any significant site conditions upstream or downstream that may influence the stream's stage: -

Watershed storage area (in percent): - _ \%

The watershed storage area is: - _ (1-mainly at the headwaters; 2- uniformly distributed; 3-immediatly upstream oi the site)

Water Surface Elevation Estimates for Existing Structure:

\begin{tabular}{|l|l|l|l|l|l|}
\hline Peak discharge frequency & $Q_{2.33}$ & $Q_{10}$ & $Q_{25}$ & $Q_{50}$ & $Q_{100}$ \\
Water surface elevation (ft)) & - & - & - & - & - \\
Velocity (ft/sec) & - & - & - & - & - \\
\hline
\end{tabular}

Long term stream bed changes: -

Is the roadway overtopped below the $\mathrm{Q}_{100}$ ? (Yes, No, Unknown): $\mathbf{U} \quad$ Frequency: Relief Elevation (ft): Discharge over roadway at $Q_{100}\left(f^{3} / \mathrm{sec}\right)$ :

Are there other structures nearby? (Yes, No, Unknown): $\mathbf{U}$ Upstream distance (miles): Town: If No or Unknown, type ctrl-n os Highway No. : Structure No. : Year Built:

Clear span (ft): Clear Height (ft): Full Waterway $\left(f^{2}\right)$ : 
Downstream distance (miles): Town: Year Built:

Highway No. : Structure No. : Structure Type:

Clear span (ft): Clear Height $(f t)$ : Full Waterway $\left(f t^{2}\right)$ :

Comments:

\section{USGS Watershed Data}

Watershed Hydrographic Data

Drainage area $(D A)$

Watershed storage (ST) $\mathrm{mi}^{2}$ Lake and pond area

0.03 $\mathrm{mi}^{2}$

Bridge site elevation $\mathbf{7 5 0}$ $\%$

Main channel length $\mathbf{5 . 1 2}$ $\mathrm{ft}$

Headwater elevation 1623 $\mathrm{ft}$ $10 \%$ channel length elevation $\quad \mathbf{7 8 0}$ $\mathrm{ft} \quad 85 \%$ channel length elevation $\mathrm{ft}$

Main channel slope (S) 138.03 $\mathrm{ft} / \mathrm{mi}$

Watershed Precipitation Data

Average site precipitation in Average headwater precipitation in

Maximum 2yr-24hr precipitation event $(124,2)$ in

Average seasonal snowfall (Sn) $\mathrm{ft}$ 


\section{Bridge Plan Data}

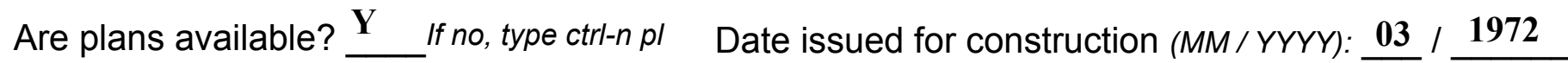
Project Number SAB $7116 \quad$ Minimum channel bed elevation: 495.0

Low superstructure elevation: USLAB $\underline{\mathbf{5 0 0 . 7}}$ DSLAB $\underline{\mathbf{5 0 0 . 7}}$ USRAB $\underline{\mathbf{5 0 0 . 9 4}}$ DSRAB $\underline{\mathbf{5 0 0 . 9 4}}$ Benchmark location description:

BM\#1, spike in a tree at the top of the downstream left wingwall and left abutment wall junction, stationing 8+50, 20 feet left, elevation 500.00 feet.

Reference Point (MSL, Arbitrary, Other): Arbitrary $\quad$ Datum (NAD27, NAD83, Other): Foundation Type: 1 (1-Spreadfooting; 2-Pile; 3- Gravity; 4-Unknown)

If 1: Footing Thickness $1.5 \quad$ Footing bottom elevation: $\underline{\mathbf{4 9 1 . 0 0}}$

If 2: Pile Type:___ (1-Wood; 2-Steel or metal; 3-Concrete) Approximate pile driven length:

If 3: Footing bottom elevation:

Is boring information available? $\mathbf{N}$ If no, type ctrl- $n$ bi Number of borings taken: _-

Foundation Material Type: $\mathbf{3}$ (1-regolith, 2-bedrock, 3-unknown)

Briefly describe material at foundation bottom elevation or around piles:

NO FOUNDATION MATERIAL INFORMATION

Comments: 


\section{Cross-sectional Data}

Is cross-sectional data available? $\underline{\mathbf{Y}}$ If no, type ctrl-n xs

Source (FEMA, VTAOT, Other)? VTAOT

Comments: Upstream bridge face: $1+10$ along the center base line 4 feet behind the left abutment Footings: top at 492, bottom at 491; protruding $2 \mathrm{ft}$ from the abutment walls.

\begin{tabular}{|l|l|l|l|l|l|l|l|l|l|l|l|}
\hline Station & $\mathbf{4 . 0}$ & $\mathbf{1 4 . 0}$ & $\mathbf{2 4 . 0}$ & & & & & & & & \\
\hline Feature & LCL & chan & LCR & & & & & & & & \\
\hline $\begin{array}{l}\text { Low cord } \\
\text { elevation }\end{array}$ & $\mathbf{5 0 0 . 5}$ & & $\mathbf{5 0 0 . 5}$ & & & & & & & & \\
\hline $\begin{array}{l}\text { Bed } \\
\text { elevation }\end{array}$ & $\mathbf{4 9 5 . 0}$ & $\mathbf{4 9 5 . 0}$ & $\mathbf{4 9 5 . 0}$ & & & & & & & & \\
\hline $\begin{array}{l}\text { Low cord to } \\
\text { bed length }\end{array}$ & $\mathbf{5 . 5}$ & & $\mathbf{5 . 5}$ & & & & & & & & \\
\hline Station & & & & & & & & & & & \\
\hline Feature & & & & & & & & & & & \\
\hline $\begin{array}{l}\text { Low cord } \\
\text { elevation }\end{array}$ & & & & & & & & & & & \\
\hline $\begin{array}{l}\text { Bed } \\
\text { elevation }\end{array}$ & & & & & & & & & & & \\
\hline $\begin{array}{l}\text { Low cord to } \\
\text { bed length }\end{array}$ & & & & & & & & & & & \\
\hline
\end{tabular}

Source (FEMA, VTAOT, Other)? VTAOT

Comments: Downstream bridge face: $0+80$ along the center base line.

\begin{tabular}{|l|l|l|l|l|l|l|l|l|l|l|l|}
\hline Station & $\mathbf{4 . 0}$ & $\mathbf{1 4 . 0}$ & $\mathbf{2 4 . 0}$ & & & & & & & & \\
\hline Feature & LCL & chan & LCR & & & & & & & & \\
\hline $\begin{array}{l}\text { Low cord } \\
\text { elevation }\end{array}$ & $\mathbf{5 0 0 . 5}$ & & $\mathbf{5 0 0 . 5}$ & & & & & & & & \\
\hline $\begin{array}{l}\text { Bed } \\
\text { elevation }\end{array}$ & $\mathbf{4 9 5 . 0}$ & $\mathbf{4 9 5 . 0}$ & $\mathbf{4 9 5 . 0}$ & & & & & & & & \\
\hline $\begin{array}{l}\text { Low cord to } \\
\text { bed length }\end{array}$ & $\mathbf{5 . 5}$ & & $\mathbf{5 . 5}$ & & & & & & & & \\
\hline Station & & & & & & & & & & & \\
\hline Feature & & & & & & & & & & & \\
\hline $\begin{array}{l}\text { Low cord } \\
\text { levation }\end{array}$ & & & & & & & & & & & \\
\hline $\begin{array}{l}\text { Bed } \\
\text { elevation }\end{array}$ & & & & & & & & & & & \\
\hline $\begin{array}{l}\text { Low cord to } \\
\text { bed length }\end{array}$ & & & & & & & & & & & \\
\hline
\end{tabular}




\section{APPENDIX E: \\ LEVEL I DATA FORM}


U. S. Geological Survey

Bridge Field Data Collection and Processing Form

Qa/Qc Check by: EMB Date: 2/14/95

\section{Structure Number POMFTH00020013}

Computerized by: EMB Date: $2 / 14 / 95$

Reviewd by: SAO Date: $6 / 27 / 96$

\section{A. General Location Descriptive}

1. Data collected by (First Initial, Full last name) M. WEBER

Date $(M M / D D / Y Y)$

$09 / 15 / 1994$

2. Highway District Number $\mathbf{0 4}$

County WINDSOR

Waterway (l - 6) BARNARD BROOK

Route Number $\mathbf{T H 0 2}$

Mile marker -

Town POMFRET

Road Name -

Hydrologic Unit Code: $\mathbf{0 1 0 8 0 1 0 6}$

3. Descriptive comments:

House and barn nearby on upstream left bank. Log debris on upstream left bank and branches and sticks in riffle upstream.

\section{B. Bridge Deck Observations}
4. Surface cover... LBUS 4
RBUS 4
LBDS 4
RBDS 6
Overall 4

(2b us, ds,lb,rb: 1- Urban; 2- Suburban; 3- Row crops; 4- Pasture; 5- Shrub- and brushland; 6- Forest; 7- Wetland)
5. Ambient water surface... US 2
UB 1
DS 2
(1- pool; 2- riffle)

6. Bridge structure type 1 (1- single span; 2- multiple span; 3- single arch; 4- multiple arch; 5-cylindrical culvert; 6- box culvert; or 7- other)
7. Bridge length 23
(feet)
Span length $\underline{\mathbf{2 0}}$
(feet)
Bridge width $\underline{\mathbf{3 1 . 3}}$ (feet)

\section{Road approach to bridge:}
8. LB 0
RB 2
( 0 even, 1- lower, 2- higher)
9. LB
RB 1
(1- Paved, 2- Not paved)

10. Embankment slope (run / rise in feet / foot)

US left -:1

US right $\quad 2.6: 1$

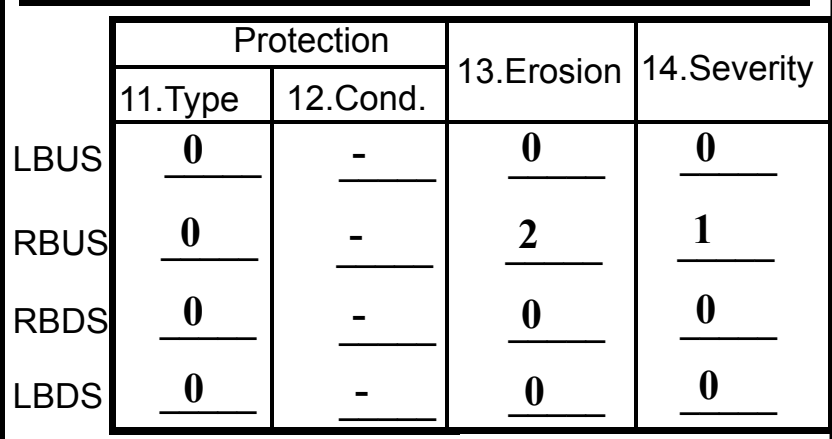

Bank protection types: 0- none; 1- < 12 inches;

2- < 36 inches; 3- < 48 inches;

4- < 60 inches; 5- wall / artificial levee

Bank protection conditions: 1- good; 2- slumped;

3- eroded; 4- failed

Erosion: 0 - none; 1- channel erosion; 2 -

road wash; 3- both; 4- other

Erosion Severity: 0 - none; 1- slight; 2- moderate; 3- severe

\section{Channel approach to bridge (BF):}

15. Angle of approach: $\mathbf{3 5}$

16. Bridge skew: $\mathbf{3 0}$

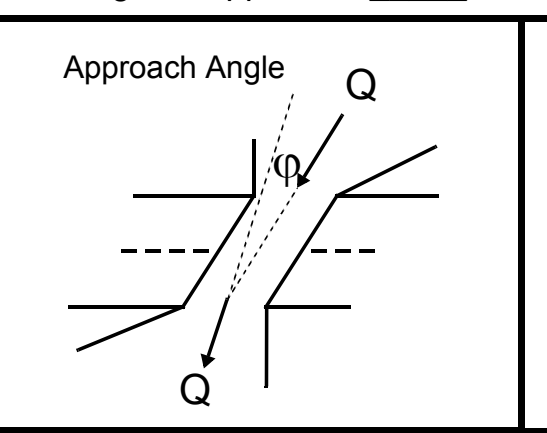

17. Channel impact zone 1:

Where? LB $(L B, R B)$

Range? 10 feet $\underline{\mathbf{U B}}$ (US,

Channel impact zone 2:

Where? $(L B, R B)$

Range? - $\quad$ feet -

(US, UB, DS) to feet -

Impact Severity: 0- none to very slight; 1-Slight; 2- Moderate; 3- Severe

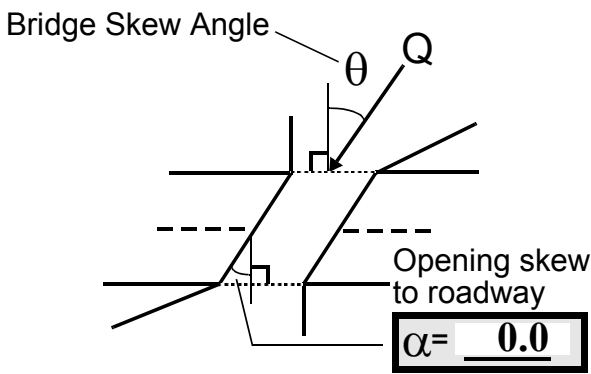

Exist? $\mathbf{Y}(Y$ or $N)$

Severity 3

$U B, D S)$ to $\underline{\mathbf{5 0}}$ feet $\underline{\mathbf{U S}}$

Exist? $\mathbf{N}(Y$ or $N)$

Severity - 
18. Level II Bridge Type: $1 \mathbf{a} / \mathbf{4}$

1a- Vertical abutments with wingwalls

$1 \mathrm{~b}$ - Vertical abutments without wingwalls

2- Vertical abutments and wingwalls, sloping embankment

Wingwalls perpendicular to abut. face

3- Spill through abutments

4- Sloping embankment, vertical wingwalls and abutments

1a with wingwalls

Wingwall angle less than $90^{\circ}$.

19. Bridge Deck Comments (surface cover variations, measured bridge and span lengths, bridge type variations, approach overflow width, etc.)

Gravel driveway on downstream left overbank. Paved road along upstream right bank. Approach channel makes a severe bend into the bridge opening. Upstream left does not have an actual roadway embankment.

\section{Upstream Channel Assessment}

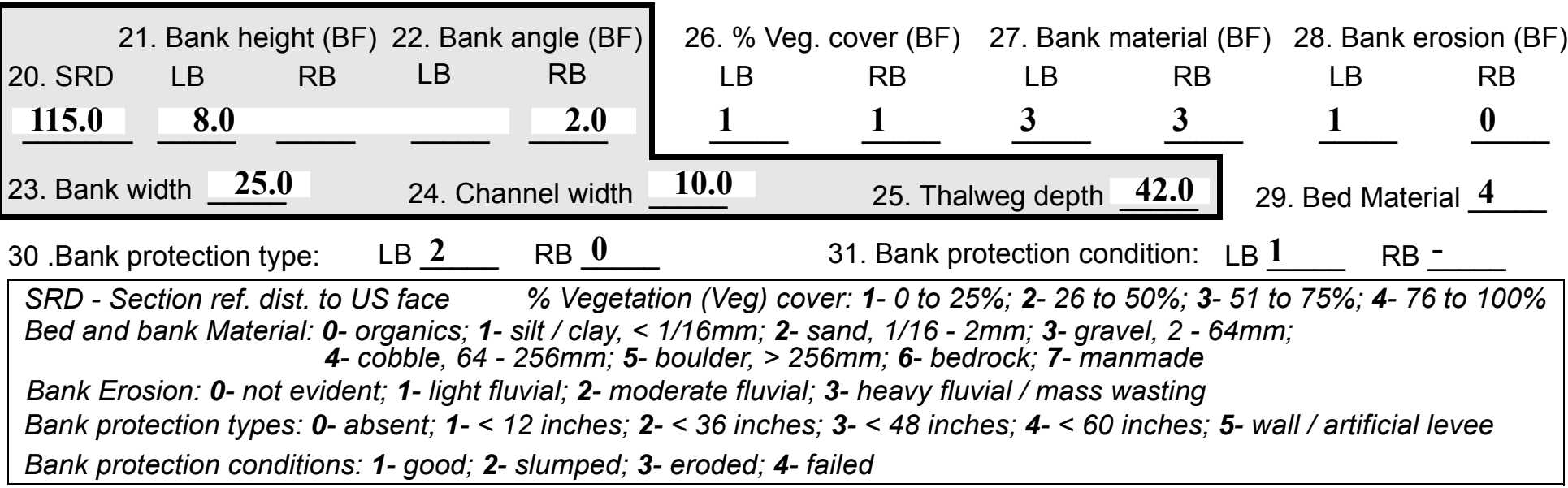

32. Comments (bank material variation, minor inflows, protection extent, etc.): 
33.Point/Side bar present? $\mathbf{Y}(Y \text { or } N \text {. if } N \text { type ctrl-n } p b)_{34}$. Mid-bar distance: $\mathbf{0}$

35. Mid-bar width: 8

36. Point bar extent: 21 feet $\underline{\mathbf{U S}}$ (US, UB) to $\underline{\mathbf{1 7}}$ feet $\underline{\mathrm{DS}}$ (US, UB, DS) positioned $\underline{\mathbf{5 0}} \%$ LB to $\underline{\mathbf{1 0 0}} \%$

37. Material: 2

38. Point or side bar comments (Circle Point) or Side; Note additional bars, material variation, status, etc.):

Mid-bar distance coincides with the downstream bridge face. Point bar extends from 21 feet upstream of the bridge to 17 feet downstream of the bridge. Bridge is 32 feet wide, thus total length of point bar is $70 \mathrm{ft}$.

39. Is a cut-bank present? $\mathbf{N}$ (Y or if $N$ type ctrl-n cb)

40. Where? - $(L B$ or $R B)$

41. Mid-bank distance: -

42. Cut bank extent: -

feet -

(US, UB) to feet (US, UB, DS)

43. Bank damage: -

(1- eroded and/or creep; 2- slip failure; 3- block failure)

44. Cut bank comments (eg. additional cut banks, protection condition, etc.):

No cut banks

45. Is channel scour present? $\mathbf{Y}$ ( $Y$ or if $N$ type ctrl-n cs)

47. Scour dimensions: Length $\underline{\mathbf{4 0}}$ Width $\mathbf{5}$

Depth : 20

46. Mid-scour distance: $\mathbf{0}$

48. Scour comments (eg. additional scour areas, local scouring process, etc.):

Scour is $\mathbf{2 . 5}$ feet deep in the deepest part of the hole along the left abutment. Deepest scour is at 11 feet under

bridge from the upstream bridge face.

49. Are there major confluences? $\mathbf{N}$

( $Y$ or if $N$ type ctrl-n $m c)$

51. Confluence 1: Distance -

52. Enters on -

Enters on - $\quad(L B$ or $R B)$

Confluence 2: Distance -

54. Confluence comments (eg. confluence name):

No confluences.

\section{Under Bridge Channel Assessment}

55. Channel restraint (BF)? LB 2 (1- natural bank; 2- abutment; 3- artificial levee)

\begin{tabular}{|cccc|cccc}
\hline \multicolumn{2}{l}{56. Height (BF) } & \multicolumn{2}{c}{57 Angle (BF) } & \multicolumn{2}{c}{ 61. Material (BF) } & \multicolumn{2}{c}{ 62. Erosion (BF) } \\
LB & RB & LB & RB & LB & RB & LB & RB \\
$\mathbf{1 3 . 0}$ & & & & $\mathbf{1 . 0}$ & & &
\end{tabular}

58. Bank width (BF) -

59. Channel width (Amb) -

60. Thalweg depth (Amb) $\mathbf{9 0 . 0}$

63. Bed Material -

Bed and bank Material: 0- organics; 1- silt / clay, < 1/16mm; 2- sand, 1/16 - 2mm; 3- gravel, 2 - 64mm; 4- cobble, 64 - 256mm; 5- boulder, > 256mm; 6- bedrock; 7- manmade

Bank Erosion: 0- not evident; 1- light fluvial; 2- moderate fluvial; 3- heavy fluvial / mass wasting

64. Comments (bank material variation, minor inflows, protection extent, etc.):

4 
65. Debris and Ice Is there debris accumulation?

$(Y$ or $N)$ 66. Where? $\underline{Y}$

(1- Upstream; 2- At bridge; 3- Both)

67. Debris Potential 1 (1-Low; 2-Moderate; 3- High)

68. Capture Efficiency 1

(1-Low; 2- Moderate; 3- High)

69. Is there evidence of ice build-up? 1 ( $Y$ or $N)$

Ice Blockage Potential $\underline{\mathbf{Y}}$

(1- Low; 2- Moderate; 3- High)

70. Debris and Ice Comments:

1

There are some small logs/branches in the upstream channel.

\begin{tabular}{|l|c|c|c|c|c|c|c|c|}
\hline Abutments & $\begin{array}{c}\text { 71. Attack } \\
\angle \text { (BF) }\end{array}$ & $\begin{array}{c}\text { 72. Slope } \angle \\
\text { (Qmax) }\end{array}$ & $\begin{array}{c}\text { 73. Toe } \\
\text { loc. (BF) }\end{array}$ & $\begin{array}{c}\text { 74. Scour } \\
\text { Condition }\end{array}$ & $\begin{array}{c}75 . \text { Scour } \\
\text { depth }\end{array}$ & $\begin{array}{c}\text { 76. Exposure } \\
\text { depth }\end{array}$ & 77. Material & 78. Length \\
\hline LABUT & & $\mathbf{3 0}$ & $\mathbf{9 0}$ & $\mathbf{2}$ & $\mathbf{1}$ & $\mathbf{2}$ & & $\mathbf{9 0 . 0}$ \\
\hline RABUT & $\mathbf{1}$ & - & $\mathbf{9 0}$ & & & $\mathbf{0}$ & $\mathbf{0}$ & $\mathbf{2 0 . 0}$ \\
\hline
\end{tabular}

Pushed: $L B$ or RB

Toe Location (Loc.): 0- even, 1- set back, 2- protrudes

Scour cond.: 0- not evident; 1- evident (comment); 2- footing exposed; 3-undermined footing; 4- piling exposed; 5- settled; 6- failed

Materials: 1- Concrete; 2- Stone masonry or drywall; 3- steel or metal; 4- wood

79. Abutment comments (eg. undermined penetration, unusual scour processes, debris, etc.):

$-$

1

Abutments constrict the channel slightly. There is scour along the left abutment where the flow impacts the upstream left wingwall and left abutment.

80. Wingwalls:

Exist? Material? Scour Scour Exposure Angle? Length? Condition? depth? depth?

USLWW:

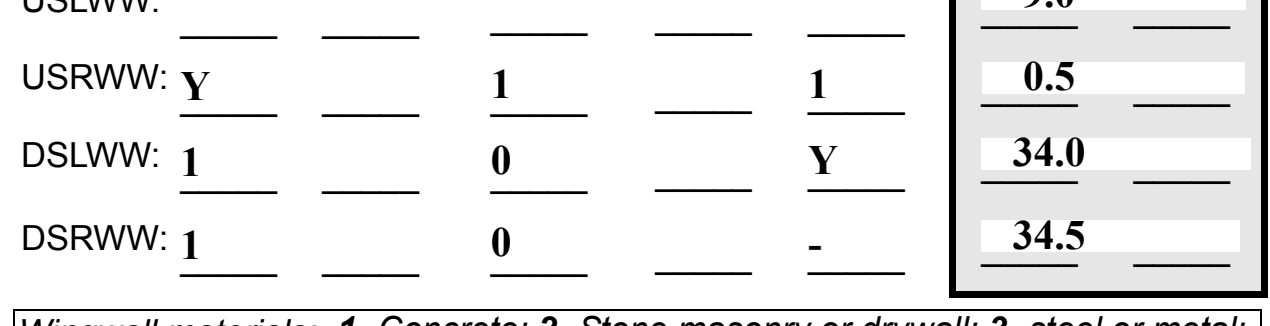

Wingwall materials: 1- Concrete; 2- Stone masonry or drywall; 3- steel or metal; 4- wood

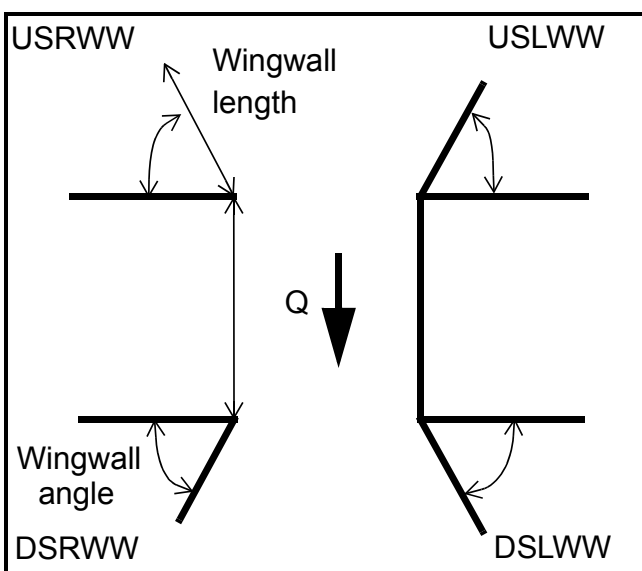

82. Bank / Bridge Protection:

\begin{tabular}{|l|l|l|l|l|l|l|l|c|}
\hline Location & USLWW & USRWW & LABUT & RABUT & LB & RB & DSLWW & DSRWW \\
\hline Type & - & $\mathbf{1}$ & $\mathbf{Y}$ & - & $\mathbf{1}$ & - & - & - \\
\hline Condition & $\mathbf{Y}$ & $\mathbf{1}$ & $\mathbf{1}$ & - & $\mathbf{1}$ & - & - & - \\
\hline Extent & $\mathbf{1}$ & $\mathbf{0}$ & $\mathbf{0}$ & $\mathbf{2}$ & $\mathbf{0}$ & $\mathbf{0}$ & $\mathbf{0}$ & - \\
\hline
\end{tabular}

Bank / Bridge protection types: 0- absent; 1- < 12 inches; 2- < 36 inches; 3- < 48 inches; 4- < 60 inches; 
83. Wingwall and protection comments (eg. undermined penetration, unusual scour processes, etc.):

-
-
-
-
-
0
-
-
0
-
-

\section{Piers:}

84. Are there piers? Mo (Y or if $N$ type ctrl-n pr)

\begin{tabular}{|l|r|r|l|l|l|l|l|}
\hline \multirow{2}{*}{$\begin{array}{l}85 . \\
\text { Pier no. }\end{array}$} & \multicolumn{3}{|c|}{ width (w) feet } & \multicolumn{3}{c|}{ elevation (e) feet } \\
\cline { 2 - 8 } & w1 & w2 & w3 & e@w1 & e@w2 & e@w3 \\
\hline Pier 1 & & & & $\mathbf{7 5 . 0}$ & $\mathbf{1 0 . 0}$ & $\mathbf{4 5 . 0}$ \\
\hline Pier 2 & $\mathbf{9 . 5}$ & $\mathbf{9 . 5}$ & & $\mathbf{4 5 . 0}$ & $\mathbf{4 5 . 0}$ & $\mathbf{1 0 . 0}$ \\
\hline Pier 3 & - & - & - & - & - & - \\
\hline Pier 4 & - & - & - & - & - & - \\
-
\end{tabular}

\begin{tabular}{|l|l|l|l|l|}
\hline Level 1 Pier Descr. & \multicolumn{1}{|c|}{1} & 2 & 3 & \multicolumn{1}{|c|}{} \\
\hline 86. Location (BF) & stly & & - & - \\
\hline 87. Type & type- & & - & - \\
\hline 88. Material & 2, & & - & - \\
\hline 89. Shape & some & & - & - \\
\hline 90. Inclined? & type- & & - & - \\
\hline 91. Attack $\angle$ (BF) & 3 & & - & - \\
\hline 92. Pushed & stone & N & - & - \\
\hline 93. Length (feet) & - & - & - & - \\
\hline 94. \# of piles & - fill. & - & - & - \\
\hline 95. Cross-members & & - & - & - \\
\hline 96. Scour Condition & & - & - & - \\
\hline 97. Scour depth & & - & - & - \\
\hline 98. Exposure depth & & - & - & - \\
\hline
\end{tabular}

LFP, LTB, LB, MCL, MCM, MCR, RB, RTB, RFP

1- Solid pier, 2-column, 3- bent

1-Wood; 2- concrete; 3- metal; 4- stone

1- Round; 2- Square; 3- Pointed

Y-yes; $N-$ no

$L B$ or $R B$

0- none; 1- laterals; 2- diagonals; 3- both

0- not evident; 1- evident (comment);

2- footing exposed; 3- piling exposed;

4- undermined footing; 5- settled; 6- failed 
99. Pier comments (eg. undermined penetration, protection and protection extent, unusual scour processes, etc.):

-
-
-
-
-
-
-
-
-
-

100.

\section{E. Downstream Channel Assessment}

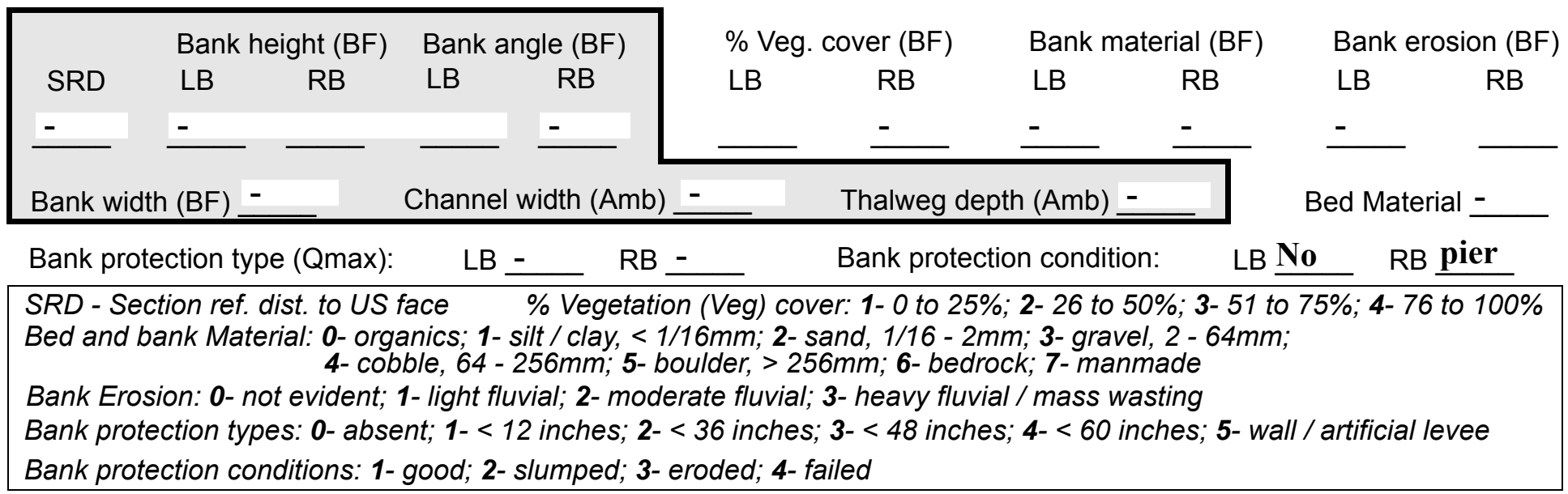

Comments (eg. bank material variation, minor inflows, protection extent, etc.):

$\mathbf{S}$

1

3

3

3

1

101. Is a drop structure present? 1 ( $Y$ or $N$, if $N$ type ctrl-n ds) 102. Distance: _ _ feet 103. Drop: -_ feet 104. Structure material: 4 (1- steel sheet pile; 2- wood pile; 3- concrete; 4- other) 105. Drop structure comments (eg. downstream scour depth): $\mathbf{0}$

$\mathbf{0}$

$-$

Some erosion along the bottoms of each bank. 
Point bar extent: feet

(US, UB, DS) to feet (US, UB, DS) positioned $\%$ LB to $\% \mathrm{RB}$

Material:

Point or side bar comments (Circle Point or Side; note additional bars, material variation, status, etc.):

$\mathbf{N}$

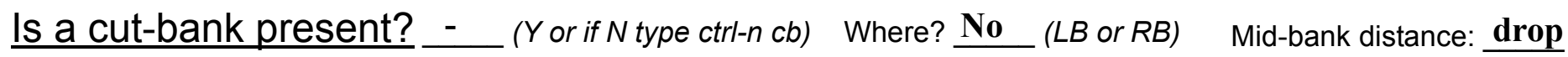
Cut bank extent: struc feet tur (US, UB, DS) to $\underline{\mathbf{e}}$ feet ___ (US, UB, DS)

Bank damage: (1- eroded and/or creep; 2- slip failure; 3- block failure)

Cut bank comments (eg. additional cut banks, protection condition, etc.):

$\mathbf{N}$

Is channel scour present? ( $Y$ or if $N$ type ctrl-n cs)

Mid-scour distance: -

Scour dimensions: Length Width Depth: -

Positioned $\%$ LB to $\% \mathrm{RB}$ Scour comments (eg. additional scour areas, local scouring process, etc.):

-

$-$

\section{No point bars}

Are there major confluences? ( $Y$ or if $N$ type ctrl-n $m c)$

How many?

Confluence 1: Distance $\mathbf{N}$ Enters on (LB or $R B$ )

Type (1-perennial; 2- ephemeral)

Confluence 2: Distance Enters on (LB or $R B)$

Type (1- perennial; 2- ephemeral)

Confluence comments (eg. confluence name):

\section{F. Geomorphic Channel Assessment}

107. Stage of reach evolution No

1- Constructed

2- Stable

3- Aggraded

4- Degraded

5- Laterally unstable

6- Vertically and laterally unstable 
108. Evolution comments (Channel evolution not considering bridge effects; See HEC-20, Figure 1 for geomorphic descriptors):

cut banks

$\mathbf{N}$

$-$

$-$

$-$

$-$

$-$

$-$

No channel scour

N

-

-

-

$-$

$-$

$-$

-

No major confluences

\section{2}

Overall stream is stable. Meanders are fairly well incised and banks are vegetated with larger woody growth beyond two bridge lengths from the bridge site. Lateral instability may be a concern at the bridge since the structure is located on a sharp bend. Flood flows would likely overtop the bridge and probably cut off the large downstream meander bend before re-entering the main channel.

Geomorphic factors affecting stream stability:

Small stream 


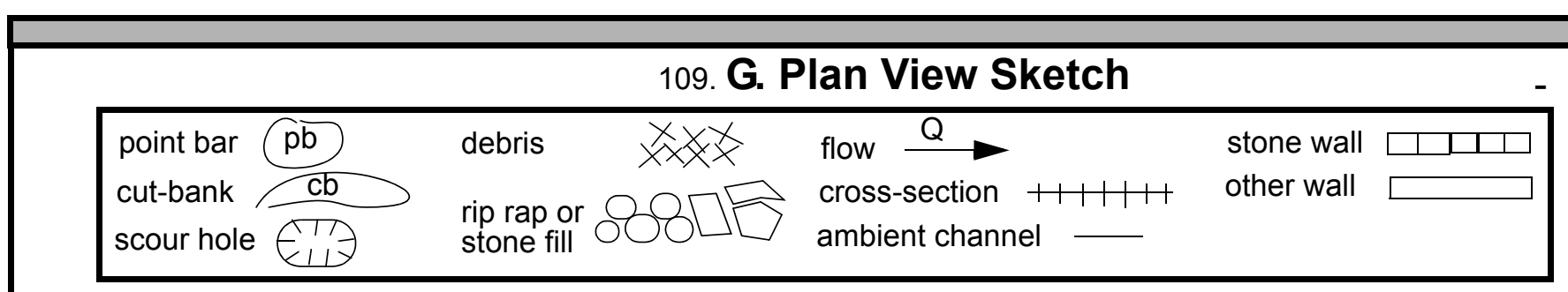


APPENDIX F:

SCOUR COMPUTATIONS 


\section{SCOUR COMPUTATIONS}

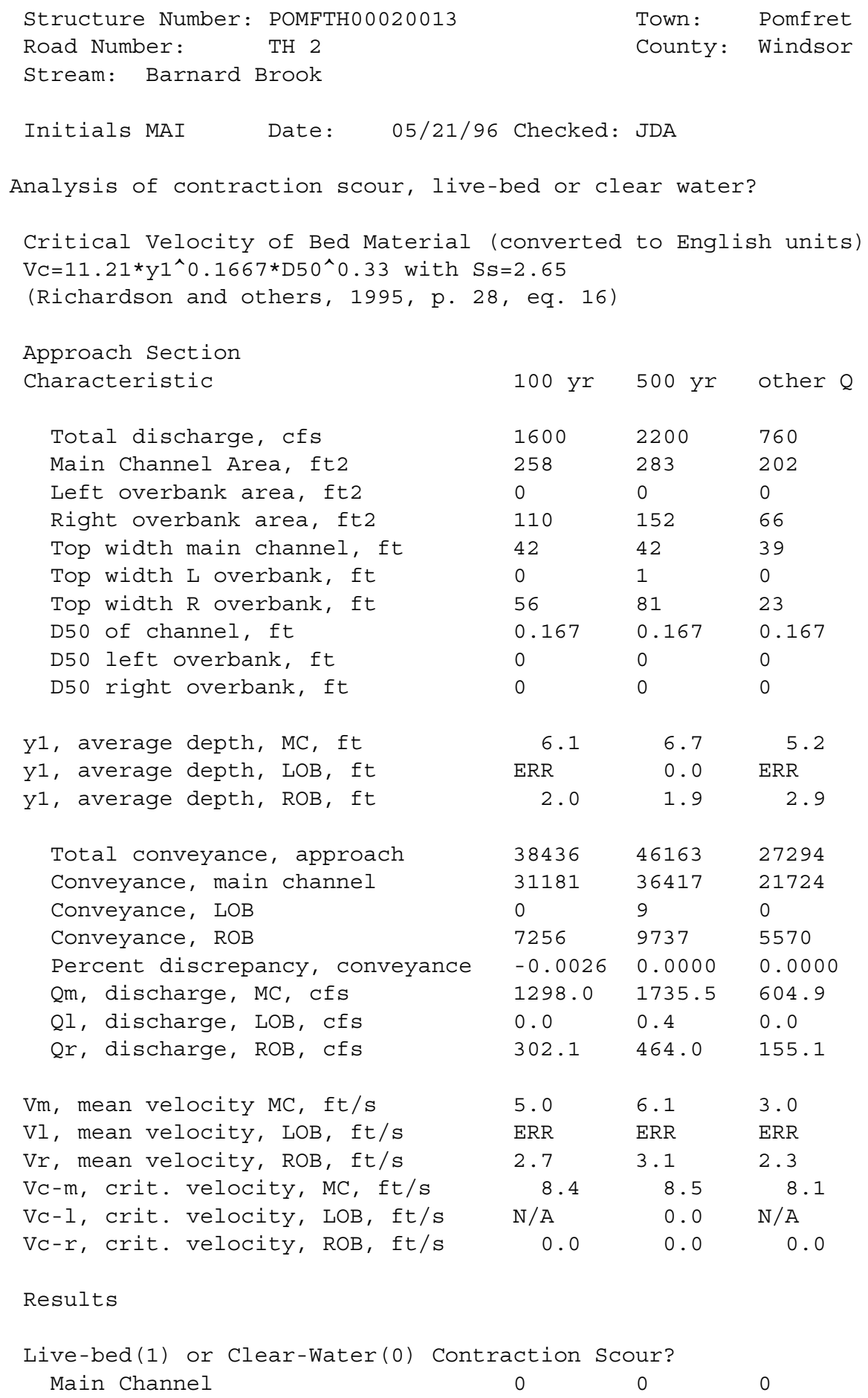


Clear water Contraction Scour in MAIN CHANNEL

\begin{tabular}{|c|c|c|c|}
\hline \multicolumn{4}{|c|}{$\mathrm{y}^{2}=\left(\mathrm{Q} 2^{\wedge} 2 /\left(131 * \mathrm{Dm}^{\wedge}(2 / 3) * \mathrm{~W} 2^{\wedge} 2\right)\right)^{\wedge}(3 / 7)$} \\
\hline (Richardson and others, 1995, p. 3 & , eq. 20 & 20 a) & \\
\hline Approach Section & Q100 & Q500 & Qother \\
\hline Main channel Area, ft2 & 258 & 283 & 202 \\
\hline Main channel width, ft & 42 & 42 & 39 \\
\hline y1, main channel depth, ft & 6.14 & 6.74 & 5.18 \\
\hline Bridge Section & & & \\
\hline (Q) total discharge, cfs & 1600 & 2200 & 760 \\
\hline (Q) discharge thru bridge, cfs & 1107 & 1051 & 760 \\
\hline Main channel conveyance & 7129 & 7129 & 7129 \\
\hline Total conveyance & 7129 & 7129 & 7129 \\
\hline Q2, bridge MC discharge, cfs & 1107 & 1051 & 760 \\
\hline Main channel area, ft2 & 113 & 113 & 113 \\
\hline Main channel width (skewed), ft & 19.9 & 19.9 & 19.9 \\
\hline Cum. width of piers in MC, ft & 0.0 & 0.0 & 0.0 \\
\hline W, adjusted width, ft & 19.9 & 19.9 & 19.9 \\
\hline y_bridge (avg. depth at br.), ft & 5.65 & 5.65 & 5.65 \\
\hline$\overline{\mathrm{Dm}}$, median $(1.25 * \mathrm{D} 50)$, ft & 0.20875 & 0.20875 & 0.20875 \\
\hline $\mathrm{y}^{2}$, depth in contraction, ft & 6.07 & 5.80 & 4.39 \\
\hline ys, scour depth (y2-ybridge), ft & 0.41 & 0.15 & -1.26 \\
\hline ARMORING & & & \\
\hline D90 & 0.32 & 0.32 & 0.32 \\
\hline D95 & 0.412 & 0.412 & 0.412 \\
\hline Critical grain size,Dc, ft & 0.3383 & 0.3049 & 0.1594 \\
\hline Decimal-percent coarser than DC & 0.089 & 0.11 & 0.537 \\
\hline Depth to armoring, ft & 10.39 & 7.40 & 0.41 \\
\hline
\end{tabular}

PRESSURE FLOW SCOUR COMPUTATION

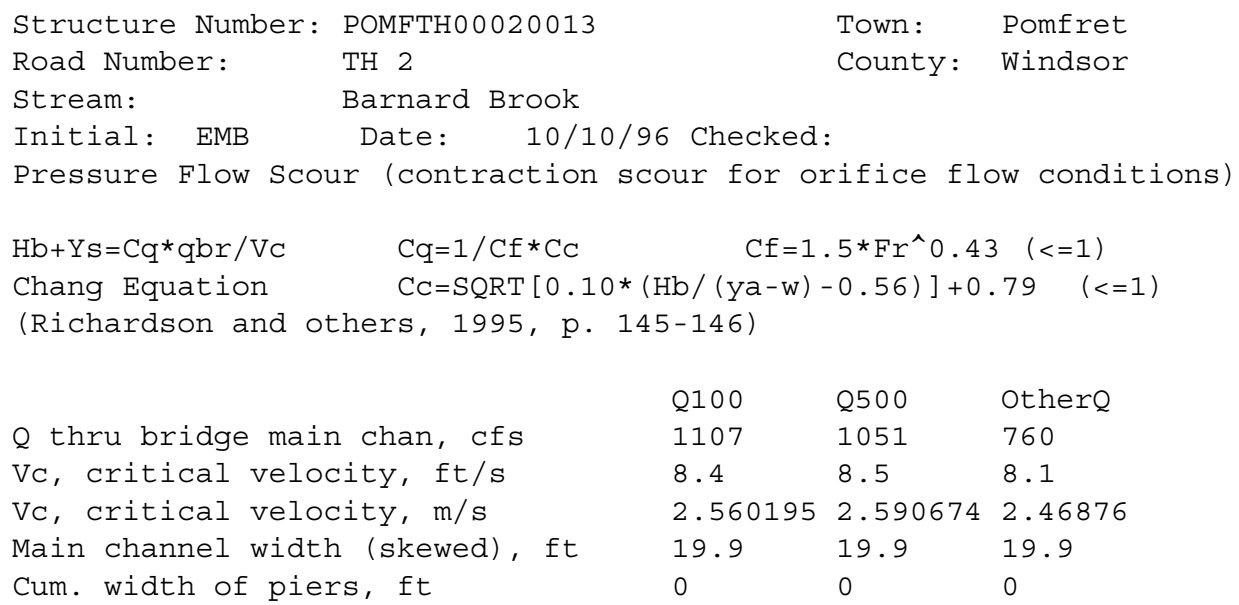




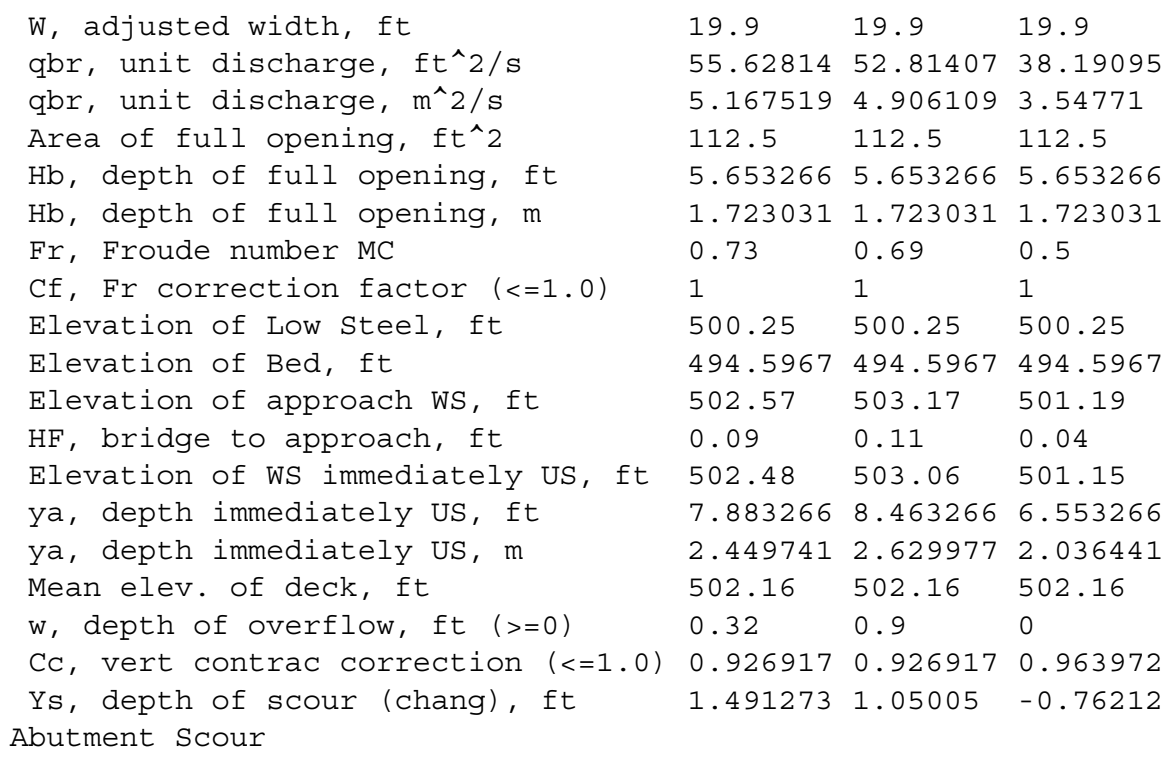

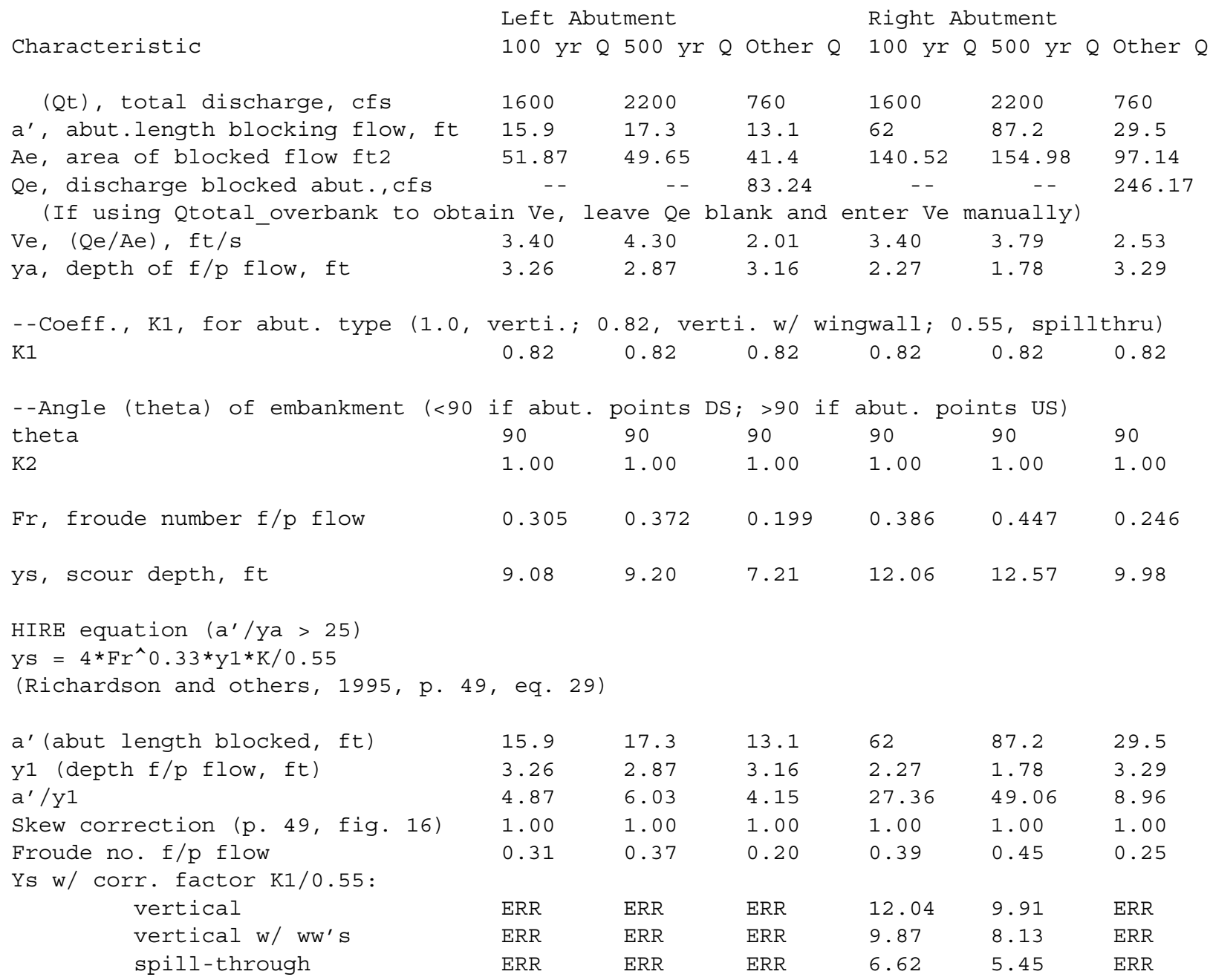




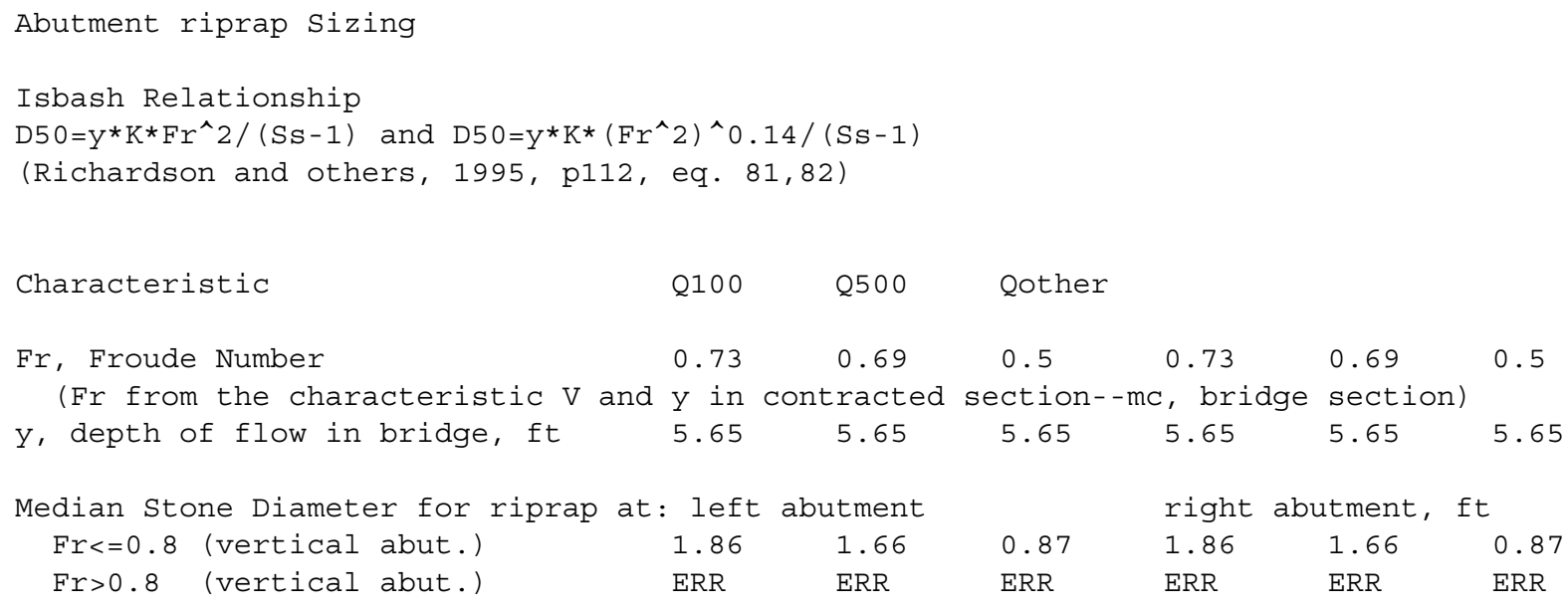

